Article

\title{
Preparation of a Hybrid Membrane from Whey Protein Fibrils and Activated Carbon to Remove Mercury and Chromium from Water
}

\author{
Laura Cristina Ramírez-Rodríguez ${ }^{1}$ (D) , Luis Eduardo Díaz Barrera ${ }^{2,3}$ (D), \\ María Ximena Quintanilla-Carvajal ${ }^{3}$, Didilia Ileana Mendoza-Castillo ${ }^{4,5}$ (D), \\ Adrián Bonilla-Petriciolet ${ }^{5}$ id and Carlos Jiménez-Junca ${ }^{2, *}$ \\ 1 Maestría en Diseño y Gestión de Procesos Facultad de Ingeniería, Campus Universitario Puente del Común, \\ Universidad de la Sabana, Km. 7 Autopista Norte, 140013 Chía, Colombia; lauraramro@unisabana.edu.co \\ 2 Bioprospecting Research Group, Campus Universitario Puente del Común, Universidad de La Sabana, Km. 7 \\ Autopista Norte, 140013 Chía, Colombia; luis.diaz1@unisabana.edu.co \\ 3 Agroindustrial Processes Research Group, Campus Universitario Puente del Común, Universidad de La \\ Sabana, Km. 7 Autopista Norte, 140013 Chía, Colombia; maria.quintanilla1@unisabana.edu.co \\ 4 Cátedras CONACYT, Instituto Tecnológico de Aguascalientes, Avenida Adolfo López Mateos \#1801, \\ Aguascalientes 20256, Mexico; didi_men@hotmail.com \\ 5 Departamento de Ingeniería Química, Instituto Tecnológico de Aguascalientes, \\ Aguascalientes 20256, Mexico; petriciolet@hotmail.com \\ * Correspondence: carlos.jimenez@unisabana.edu.co; Tel.: +57-861-5555-25010
}

Received: 22 October 2020; Accepted: 25 November 2020; Published: 30 November 2020

check for updates

\begin{abstract}
Water contamination by mercury and chromium has a direct effect in human health A promising technology to remove heavy metals by membrane filtration is the use of hybrid membranes produced with whey protein fibrils (WPF) and activated carbon (AC). In this study, the best conditions to produce WPF by heat treatment were determined to maximize the removal of mercury and chromium from water using a central composed design. The results indicated that the best conditions to prepare WPF were $74{ }^{\circ} \mathrm{C}, 7 \mathrm{~h}$ and $3.8 \%$ of whey protein with adsorption capacities of 25 and $18 \mathrm{mg} / \mathrm{g}$ and removal efficiencies of 81 and $57 \%$ for mercury and chromium, respectively. WPF and AC were used to prepare a hybrid membrane that was characterized using transmission electron microscopy, atomic force microscopy, scanning electron microscopy, Fourier transform infrared spectroscopy and Brunauer-Emmett-Teller surface area measurements. Batch filtration experiments were performed with the hybrid membrane for chromium and mercury removal at 25, 50 and $100 \mathrm{mg} / \mathrm{L}$ to determine its adsorption capacities. A high performance of the hybrid membrane was demonstrated removing efficiently mercury and chromium from water, thus supporting more than ten filtration cycles.
\end{abstract}

Keywords: activated carbon; heavy metals; membrane; protein water treatment; whey

\section{Introduction}

Water pollution affects millions of people around the world, which leads to health problems and can cause death in populations under extreme conditions [1]. The major sources of water pollution by toxic ions are unregulated industries, energy production and mining, which have substantially increased the pollutants concentration in water [2]. Heavy metal ions are not biodegradable and have a massive effect in the ecosystem. As a result, their bioaccumulation and biomagnification are present in organisms and the food chain [3]. Therefore, heavy metals cause serious health risks and environmental impacts [4]. 
Chromium and mercury are recognized as a potential risk to human health and the environment due to their carcinogenic, toxic and mutagenic nature. Chromium, especially its hexavalent state (Cr (VI)), is toxic, soluble in water, has high mobility and can induce autophagy of human stem cells [5]. This metal is used in steel industries, pigments manufacture, the electroplating industry and as a leather tanning agent [6]. Likewise, mercury is considered the most toxic heavy metal in the environment and is one of the priority pollutants according to the US EPA [7]. Owing to the transformation of mercury by microorganisms into methylmercury, it is bio-magnified in the environment causing adverse effects in organisms. The main sources of mercury pollution are agriculture, urban wastewater, mining, incineration and industrial wastewater [8].

To remove heavy metal ions from water, various physical and chemical methods have been used, such as chemical precipitation [4], flocculation, coagulation [9], ion-exchange [10] and electrochemical treatment techniques [11]. However, the implementation of these techniques faces economic or environmental constraints owing to the high cost, demanding additional processes to eliminate waste products, specific operating conditions to ensure an acceptable decontamination, and some of these techniques face the problem that they could be effective to remove only one specific heavy metal ion [6]. Among these methods for heavy metal removal, adsorption is an efficient technology because of its simple operation, low operating cost (especially, energy), low sludge production and the recyclability of the adsorbent to remove metal ions from dilute and concentrated effluents [12]. However, adsorption has some disadvantages, such as the high cost of commercial adsorbents and a difficult implementation with respect to the removal of complex ions [13]. Consequently, a promising and emerging technology is the production of adsorbent membranes due to it combining the adsorption properties of the material and the filtration performance of the membrane [14,15]. Research efforts have focused on the use of hybrid materials such as protein amyloids and activated carbon for wastewater treatment, which include the development of new types of membranes by self-assembly of adsorbents [16-18].

In this way Bolisetty and Mezzenga [16] produced amyloid fibrils by heat treatment using $\beta$-lactoglobulin to obtain a hybrid membrane with activated carbon, which was able to remove more than $99.5 \%$ of gold, mercury, lead and palladium, individually and mixed, in aqueous solution. Using the same type of membrane, 99\% of arsenites and arsenates were removed from prepared solutions and contaminated real water [17]. To comprehend the mechanisms of the metal ion binding with $\beta$-lactoglobulin amyloids, Peydayesh et al. [18] studied the adsorption isotherms using isothermal thermal calorimetry (ITC) on native $\beta$-lactoglobulin monomers. This study was performed on the removal of chromium $(\mathrm{Cr})$, nickel $(\mathrm{Ni})$, silver $(\mathrm{Ag})$ and platinum $(\mathrm{Pt})$, where the results showed removal efficiencies beyond $99 \%$.

Similarly, Mezzenga et al. [19] reported the use of hybrid membranes made of $\beta$-lactoglobulin amyloid fibrils-ZrO2 nanoparticles $(<10 \mathrm{~nm})$ that efficiently removed fluoride from polluted water. These hybrid membranes presented a high selectivity for fluoride against various competitive ions and exceeded the performance of most commercial carbon-activated aluminum membranes. The efficiency of the membrane exceeded $99.5 \%$ removal.

Additionally, Yu et al. [2] produced a hybrid membrane for the detection and separation of mercury ion, which was produced by filtrating gold nanocluster with bovine serum albumin nanofibers and graphene oxide. These membranes presented a removal efficiency of mercury up to $90.4 \%$ in the first cycle. Furthermore, Yu et al. [2] reported the preparation of a graphene oxide (GO)-bovine serum albumin (BSA) hybrid membrane for metal ions detection, which has a large surface area and a high metal-binding ability due to BSA.

These studies demonstrated interesting results for heavy metal removal from water using these types of hybrid membranes. The high performance of the membranes is due to the synergy of high metal binding capacity of proteins with a high surface area material [18]. From these works, it can be concluded that most of the hybrid membranes involve $\beta$-lactoglobulin or BSA alone as a protein source, which opens the opportunity to produce hybrid membranes from a mix of proteins like whey. 
Whey is a by-product of the cheese industry composed mainly by $\beta$-lactoglobulin (60\%) and $\alpha$-lactalbumin $(20 \%)$, which causes a pollution problem especially in countries connected to the milk economy because nine kilograms of whey are generated per each kilogram of cheese [20,21]. Yet, in nations such as U.S., Australia and China, whey manufacture and consumption are growing mainly due to infants and sport nutrition, with an annual growth rate of $8.1 \%$ [22] and an average price of 6 USD/Kg for 2018 [21]. Despite this, some companies have tried to enter the market of protein isolation by fractionation but lacked success due to the added value in the production price of isolated proteins, such as $\beta$-lactoglobulin, which costs 5.43 USD per kilogram of treated whey protein isolate (WPI) [23] and also includes a cumbersome and time-consuming additional process [24,25]. For that reason, an application at large scale using a hybrid adsorbent of $\beta$-lactoglobulin, as proposed in a number of studies [16-18], is not viable due to the high cost of the protein purification [26].

Consequently, the use of whey is an opportunity to make hybrid materials that have many advantages owing to the combination of the properties of the components and strong economic incentives. Thus, in this study, whey protein fibrils (WPF) were used to prepare a hybrid membrane with activated carbon $(\mathrm{AC})$ because it is a well-known adsorption material owing to its large surface area and can provide mechanical support to WPF. Additionally, the use of hybrid materials may lead to a lower-cost material than activated carbon $(10 \mathrm{USD} / \mathrm{Kg})[27,28]$ alone because of the combination of a low-cost feedstock, as whey, with activated carbon. This novel hybrid membrane was tested for mercury and chromium removal from water. This work considered it important to find the optimal conditions to produce WPF from whey to remove heavy metals before preparing the hybrid membrane, which has not been reported in the literature. The results demonstrated that the production conditions of WPF affected the way proteins aggregate so that it can lead to a significant impact on the removal of mercury and chromium from water. Furthermore, this hybrid membrane showed promising performance in removing heavy metals after various filtering cycles.

\section{Materials and Methods}

\subsection{Materials}

Whey protein isolate (WPI) was purchased from Davisco Foods International Inc. (Eden Prairie, MN, USA) and it was $97 \%$ protein of which approximately $69 \%$ was $\beta$-Lactoglobulin and $22 \%$ was $\alpha$-lactalbumin. $\beta$-Lactoglobulin (>90\%), mercury chloride (II), sodium chromate and activated carbon (particle size of $45 \mu \mathrm{m}$ ) were obtained from Sigma Aldrich (St. Louis, MO, USA). All reagents were analytical grade and used as received. Nitrocellulose membranes (Sartorius Stedim Biotech, Goettingen, Germany) with a pore size of $0.22 \mu \mathrm{m}$ were used to produce the hybrid membrane.

\subsection{Preparation of Protein Fibrils}

Amyloids were prepared following the method proposed by Peydayesh et al. [18]. Solutions were prepared according to a central composited design (CCD, see Table 1), which was used to evaluate the impact of whey concentration, temperature and time on the adsorption capacity of heavy metals. This CCD included 15 trials with five levels for each factor. In particular, whey powder was dissolved in deionized water at concentrations of $0.5-5 \mathrm{wt} \%$. $\beta$-Lactoglobulin was prepared as reference at the conditions obtained by CCD and all samples were adjusted at $\mathrm{pH} 2$ because this condition ensured fibril formation due to the electrostatic repulsion among positively-charged groups, monomers and peptides preventing a random aggregation [29]. The solution was centrifuged at 10,800 RFC for $1 \mathrm{~h}$ at $20{ }^{\circ} \mathrm{C}$ using a centrifuge (Universal 32R, Tuttlingen, Germany), and filtered through a $0.45 \mu \mathrm{m}$ Millipore filter before a heat-treatment to remove any traces of undissolved protein. A volume of $15 \mathrm{~mL}$ of solution were placed in glass tubes hermetically sealed and maintained in a water bath without stirring at $65-90^{\circ} \mathrm{C}$ for $5-11 \mathrm{~h}$. After this treatment, the tubes were immediately cooled by immersion in ice-water mixtures, and also a sample that was not heated was used as reference [30]. 
Table 1. Description of the central composite design (CCD) used for WPF preparation and its impact on mercury and chromium removal from water.

\begin{tabular}{cccccccc}
\hline \multirow{2}{*}{ Variable. } & \multirow{2}{*}{ Unit } & \multirow{2}{*}{ Factors } & \multicolumn{7}{c}{ Level } \\
\cline { 4 - 8 } & & & $-\boldsymbol{\alpha}$ & $\mathbf{- 1}$ & $\mathbf{0}$ & $\mathbf{1}$ & $\boldsymbol{\alpha}$ \\
\hline Temperature & ${ }^{\circ} \mathrm{C}$ & $\mathrm{A}$ & 66 & 70 & 80 & 90 & 94 \\
Time & $\mathrm{h}$ & $\mathrm{B}$ & 5 & 6 & 8 & 10 & 11 \\
Whey concentration & $\mathrm{wt} \%$ & $\mathrm{C}$ & 0.4 & 1 & 2.5 & 4 & 4.6
\end{tabular}

$\alpha=1.41$ (star or axial point for orthogonal small CCD in the case of three independent variables and their actual values were rounded).

The experimental results of CCD were statistically studied by an analysis of variance (ANOVA). Design-Expert 10.0 software (Stat-Ease, US) was used to analyse the experimental design, response surface modelling, statistical regression analysis and process optimization. The results were fitted via the response surface regression procedure using a second order polynomial given by Equation (1) [31]:

$$
Y=\beta_{0}+\sum_{i=1}^{n} \beta_{i} x_{i}+\sum_{i=1}^{n-1} \sum_{j=i+1}^{n} \beta_{i j} x_{i} x_{j}+\sum_{i=1}^{n} \beta_{i i} x_{i}^{2}
$$

where $Y$ is the predicted response, $\beta_{0}$ is the regression coefficients, $\beta_{i}$ is the linear coefficient, $\beta_{i i}$ is the quadratic coefficients, $\beta_{i j}$ is the interaction coefficients and $X_{i}$ is the coded levels of independent variables, respectively.

\subsection{Preparation of Hybrid Membranes}

Hybrid nanomembranes were prepared using the method of Li et al. [32]. A whey fibril solution produced at the best conditions at $\mathrm{pH} 2$ was dropped into the $\mathrm{AC}$ solution $(0.1 \mathrm{wt} \%)$ with vigorous stirring to give a final mixture of 1:0, 2:1, 1:1, 1:2, 1:5 and 0:1 of AC-WPF. The protein hybrid membranes were prepared by vacuum filtration of $1.8 \mathrm{~mL}$ of the mixture solution, passing the mixture through a nitrocellulose filter of $0.22 \mu \mathrm{m}$ and diameter of $47 \mathrm{~mm}$.

\subsection{Characterization of Protein Fibrils and Hybrid Membranes}

Fibril formation was analysed by transmission electron microscopy (Quantifoil, Großlöbichau, Germany) and atomic force microscopy (Asylum Research, Goleta, CA, USA). AFM samples were held in cleaved mica sheets and rinsed with Milli-Q water. The size distributions and shapes of fibrils were measured using a cantilever operated in tapping mode for image topography. The cantilever was silicon nitride with a nominal force constant of $0.08 \mathrm{~N} / \mathrm{m}$, the scan rate was set to $1 \mathrm{~Hz}$ [33] and Gwyddion ${ }^{\circledR}$ v. 2.54 (Czech Metrology Institute, Brno, Czech republic) free software was used for image processing. The morphology of hybrid membrane was analysed with a Tescan LYRA 3 scanning electron microscope (SEM) (TESCAN, Brno, Czech Republic) at an acceleration voltage of $3 \mathrm{kV}$ [2].

The amyloid fibril formation was determined by Congo Red assay following the method proposed by Yakupova et al. [34]. A qualitative chemical characterization of fibrils, activated carbon and the hybrid composite at different compositions 1:0, 1:1, 1:2, 1:5 and 0:1 was performed by Fourier transform infrared spectroscopy (FTIR) (Thermo Scientific ${ }^{\circledR}$, Waltham, MA, USA) in the region of 4000-500 $\mathrm{cm}^{-1}$ [19]. Surface area was determined using Brunauer-Emmett-Teller (BET) method and measured by nitrogen adsorption at $77 \mathrm{~K}$ (i.e., $-196^{\circ} \mathrm{C}$ ) in a ChemBET Pulsar TPR/TPD unit (Quantachrome instruments, Boynton Beach, FL, USA) [35].

\subsection{Removal Efficiency of Heavy Metals from Water}

Batch experiments and filtration were carried out to evaluate the adsorption capacities of heavy metals on WPF and hybrid membranes. Prior to the experiment, stock aqueous solutions of mercury 
chloride (II) and sodium chromate of different initial concentrations were adjusted to $\mathrm{pH} 3.0$ using $0.1 \mathrm{M}$ of $\mathrm{HNO}_{3}$. Note that $\mathrm{Cr}$ and $\mathrm{Hg}$ exist as dissolved anion $\left(\mathrm{HCrO}_{4}{ }^{2-}\right)$ [36] and cation $\left(\mathrm{Hg}^{2+}\right)$ [37], respectively, in the aqueous solution at the tested $\mathrm{pH}$ according to speciation diagrams. To determinate the removal efficiency of WPF, the solution obtained by heat treatment with a known quantity of fibrils was equilibrated $(1: 1 \mathrm{wt})$ with a heavy metal solution of $100 \mathrm{mg} / \mathrm{L}$ to have a final concentration of $50 \mathrm{mg} / \mathrm{L}$. The experiment was carried out under isothermal conditions at room temperature $\left(20^{\circ} \mathrm{C}\right)$, $\mathrm{pH} 3$ and continuous shaking ( $150 \mathrm{rpm})$ for $24 \mathrm{~h}$ to ensure the equilibrium. Finally, the resulting solution was centrifuged, filtered and analysed with a ContrAA 700 atomic absorption spectrophotometer (Analytik Jena, Jena, Germany). Blank experiments were also performed to ensure that no adsorption took place on the walls of the apparatus used.

To evaluate the removal performance of hybrid membranes, $50 \mathrm{~mL}$ of a heavy metal solution with a given initial concentration (i.e., 25, 50, $100 \mathrm{mg} / \mathrm{L}$ ) was filtered through WPF-AC hybrid membrane (note that a new membrane was available for each heavy metal concentration tested) and the metal concentration was measured before and after filtration by a ContrAA 700 atomic absorption spectrophotometer (Analytik Jena, Jena, Germany). The removal capacity was determined by filtering consecutive cycles of $50 \mathrm{~mL}$ of heavy metal solutions and the residual concentration of the metals in the filtrate was measured until a decrease in the removal efficiency, compared to the initial one, was observed. The removal of heavy metals was determined using only activated carbon and only whey protein fibrils, and these values were used as a reference [17]. The removal efficiency $(R, \%)$ and adsorption capacity (q, mg/g) [28] were calculated with the following equations:

$$
\begin{gathered}
R(\%)=\frac{C_{0}-C_{t}}{C_{0}} \times 100 \\
q=\frac{\left(C_{0}-C_{t}\right)}{m_{s}} \times V
\end{gathered}
$$

where $C_{0}$ is the initial heavy metal concentration, $C_{t}$ is the heavy metal concentration after filtration, $V$ is the heavy metal solution volume $(\mathrm{L})$ and $\mathrm{m}_{\mathrm{s}}$ is the weight of hybrid membrane $(\mathrm{g})$, respectively.

\subsection{Statistical Analysis}

Analysis of variance (ANOVA) was conducted with CDD results followed by LSD test to establish statistical differences between treatments with a significance level ( $p$-level) of 0.05. Experiments were performed in triplicate, and the results were reported as the mean and standard deviation of the measurements. SPSS V24 software was employed in data processing.

\section{Results}

\subsection{Preparation of Whey Protein Fibrils}

Results of CCD were used to determinate the best conditions to prepare WPF. The experimental data of the adsorption capacity and efficiency of WPF to remove mercury and chromium are shown in Table 2. ANOVA indicated that all tested parameters of WPF production had a significant effect $(p<0.05)$ on the adsorption capacity and efficiency for mercury, while the quadratic term associated to the temperature in the model given by Equation (1) was not significant. The same result was found for the removal efficiency of chromium, but the interaction term between temperature and protein was not significant in this model. In the literature, many researchers have concluded that the WPF aggregation and conversion by heat treatment depended of temperature, protein content and time. Therefore, the way that these factors interfere on the fibril formation may influence the adsorption of heavy metals on fibrils [38-41]. The conditions that favor the fibrils production found in the literature were used as starting point to design the experiment and to obtain whey protein fibrils. 
Table 2. Results of Central Composite Design (CCD) for WPF preparation and its impact on mercury and chromium removal from water, experimental and analytical response. Factors: A-Temperature $\left({ }^{\circ} \mathrm{C}\right), \mathrm{B}$ - time $(\mathrm{h})$ and $\mathrm{C}$ - whey concentration $(\mathrm{wt} \%)$.

\begin{tabular}{|c|c|c|c|c|c|c|c|c|c|c|c|c|c|c|c|}
\hline \multirow{3}{*}{ Run } & \multirow{3}{*}{$\mathbf{A}$} & \multirow{3}{*}{ B } & \multirow{3}{*}{$\mathrm{C}$} & \multicolumn{6}{|c|}{ Adsorption Capacity and Efficiency for $\mathbf{H g}$} & \multicolumn{6}{|c|}{ Adsorption Capacity and Efficiency for $\mathrm{Cr}$} \\
\hline & & & & \multicolumn{2}{|c|}{ Experimental } & \multicolumn{2}{|c|}{ Predicted } & \multicolumn{2}{|c|}{ Error } & \multicolumn{2}{|c|}{ Experimental } & \multicolumn{2}{|c|}{ Predicted } & \multicolumn{2}{|c|}{ Error } \\
\hline & & & & q & $\%$ & q & $\%$ & q & $\%$ & q & $\%$ & q & $\%$ & q & $\%$ \\
\hline 1 & 66 & 8 & 2.5 & 23.4 & 79 & 23.5 & 79 & 0.5 & 0.5 & 17.8 & 56 & 17.9 & 56 & 0.6 & 0.6 \\
\hline 2 & 70 & 6 & 1 & 13.9 & 47 & 13.8 & 46 & 0.9 & 0.9 & 11.4 & 36 & 11.3 & 35 & 1.1 & 1.1 \\
\hline 3 & 70 & 10 & 4 & 12.6 & 42 & 12.4 & 42 & 1.1 & 1.0 & 9.5 & 30 & 9.3 & 29 & 1.4 & 1.4 \\
\hline 4 & 80 & 5 & 2.5 & 23.0 & 78 & 23.1 & 78 & 0.5 & 0.5 & 9.8 & 31 & 9.9 & 31 & 1.1 & 1.1 \\
\hline 5 & 80 & 8 & 0.4 & 2.6 & 8 & 2.7 & 9 & 4.7 & 4.7 & 1.5 & 4 & 1.6 & 5 & 7.5 & 7.6 \\
\hline 6 & 80 & 8 & 2.5 & 21.5 & 73 & 20.1 & 68 & 6.9 & 6.9 & 7.5 & 23 & 7.7 & 24 & 2.5 & 2.5 \\
\hline 7 & 80 & 8 & 2.5 & 20.0 & 68 & 20.1 & 68 & 0.4 & 0.4 & 8.0 & 25 & 7.7 & 24 & 3.7 & 3.7 \\
\hline 8 & 80 & 8 & 2.5 & 20.2 & 68 & 20.1 & 68 & 0.7 & 0.7 & 7.4 & 23 & 7.7 & 24 & 4.0 & 4.0 \\
\hline 9 & 80 & 8 & 2.5 & 18.9 & 64 & 20.1 & 68 & 6.1 & 6.1 & 8.0 & 25 & 7.7 & 24 & 3.0 & 3.0 \\
\hline 10 & 80 & 8 & 2.5 & 20.1 & 68 & 20.1 & 68 & 0.2 & 0.3 & 7.9 & 25 & 7.7 & 24 & 2.2 & 2.2 \\
\hline 11 & 80 & 8 & 4.6 & 15.5 & 52 & 15.6 & 53 & 0.6 & 0.7 & 17.2 & 54 & 17.3 & 54 & 0.6 & 0.6 \\
\hline 12 & 80 & 11 & 2.5 & 13.0 & 44 & 13.1 & 44 & 0.8 & 0.9 & 6.6 & 21 & 6.8 & 21 & 1.6 & 1.6 \\
\hline 13 & 90 & 6 & 4 & 6.5 & 21 & 6.3 & 21 & 2.1 & 2.1 & 10.7 & 33 & 10.6 & 33 & 1.2 & 1.2 \\
\hline 14 & 90 & 10 & 1 & 24.2 & 82 & 24.1 & 81 & 0.6 & 0.5 & 6.6 & 21 & 6.5 & 20 & 2.0 & 2.0 \\
\hline 15 & 94 & 8 & 2.5 & 17.4 & 59 & 17.5 & 59 & 0.6 & 0.7 & 2.1 & 6 & 2.2 & 7 & 4.9 & 5.0 \\
\hline
\end{tabular}

A two-factor interaction and a quadratic model were used to analyze the interaction between the independent factors and the effect on adsorption capacity and removal efficiency of mercury and chromium. These models are given in Equations (4) and (5) for mercury and Equations (6) and (7) for chromium was used. $R^{2}$ was higher than 0.99 and the adjusted $R^{2}$ was higher than 0.98 for all models where lack of fit was 0.694 and 0.227 (nonsignificant) for mercury and chromium, respectively.

These models for the calculation of the adsorption capacity $\mathrm{q}(\mathrm{mg} / \mathrm{g})$ at $50 \mathrm{mg} / \mathrm{L}$ and removal efficiency (\%) for mercury and chromium were defined as follows, Equations (4)-(7):

$$
\begin{aligned}
\boldsymbol{q} \boldsymbol{H g}(\boldsymbol{m g} / \mathrm{g})= & 250.02-3.59 * A-38.88 * B+63.34 * C+0.54 * A * B-0.49 * A * C \\
& -1.01 * B * C)+0.0019 * A^{2}-0.22 * B^{2}-2.32 * C^{2}
\end{aligned}
$$

$$
\begin{aligned}
& \text { Removal Efficiency } \mathbf{H g}(\%) \\
& \qquad \begin{array}{rl}
= & 848.59-12.21 * A-131.96 * B+214.98 * C+1.83 * A * B-1.67 * A \\
* & C-3.43 * B * C+0.0064 * A^{2}-0.75 * B^{2}-7.89 * C^{2}
\end{array} \\
& \begin{aligned}
\boldsymbol{q} \mathrm{Cr}(\mathrm{mg} / \mathrm{g})= & 240.47-4.09 * A-16.22 * B+11.64 * C+0.22 * A * B+0.0306 * A * C \\
& -1.44 * B * C+0.0104 * A^{2}+0.066 * B^{2}+0.17 * C^{2}
\end{aligned}
\end{aligned}
$$

Removal Efficiency $\mathrm{Cr}(\%)$

$$
\begin{aligned}
& =762.68-12.97 * A-51.44 * B+36.93 * C+0.72 * A * B+0.097 * A * C \\
& -4.58 * B * C+0.03 * A^{2}+0.21 * B^{2}+0.54 * C^{2}
\end{aligned}
$$

where $A$ is temperature $\left({ }^{\circ} \mathrm{C}\right), B$ is time $(\mathrm{h})$ and $C$ is whey concentration $(\mathrm{wt} \%)$.

The results obtained from CCD indicated that the temperature, protein content and time had a significant effect on mercury and chromium adsorption capacity and removal efficiency. Consequently, it confirmed that these factors have a critical effect on whey proteins aggregation [39,42], which has a relationship with the mechanism to remove heavy metals from water because, depending on the way amyloid fibrils arranged, the active sites of the fibrils will be more or less available [43]. Furthermore, the models obtained in this study (Equations (4)-(7)) indicated that protein content had a positive influence on $\mathrm{Hg}$ and $\mathrm{Cr}$ removal capacity and efficiency, while temperature and time showed a negative effect on the removal of $\mathrm{Hg}$ and $\mathrm{Cr}$. For instance, there must be an equilibrium between the protein content and the heating conditions to prepare WPF. Whey solutions with high protein content submitted to high temperatures for a long heating time, instead of producing active amyloids fibrils to remove heavy metals, generate protein gels with low removal capacity [30]. As shown in 
Table 3, the best conditions to produce WPF and to improve the adsorption capacity and efficiency for mercury and chromium removal were: a temperature near to $74{ }^{\circ} \mathrm{C}$, at approximately $7 \mathrm{~h}$ with a protein concentration of $3.8 \%$. So that, the preparation conditions of WPF to remove both mercury and chromium were very similar, showing that the aggregation conditions affect the adsorption capacity and removal efficiency of these heavy metals in the same way. Also, non-heated whey protein solutions were used as reference and they did not remove $\mathrm{Hg}$ or $\mathrm{Cr}$.

Table 3. Best preparation conditions to produce WPF and to improve the adsorption capacity and removal efficiency for mercury and chromium. Validated values were expressed as mean \pm SD of triplicate.

\begin{tabular}{ccc}
\hline \multicolumn{3}{c}{ Best Preparation Conditions } \\
\hline Mercury & Chromium \\
\hline Temperature $\left({ }^{\circ} \mathrm{C}\right)$ & 74.1 & 73.5 \\
\hline Time $(\mathrm{h})$ & 7.5 & 7.1 \\
\hline $\mathrm{q}(\mathrm{mg} / \mathrm{g})$ predicted & 3.8 & 3.7 \\
\hline $\mathrm{q}(\mathrm{mg} / \mathrm{g})$ validated & 29.4 & 19.3 \\
\hline $\mathrm{q}(\mathrm{mg} / \mathrm{g})$ mixed & $24.9 \pm 0.3$ & $17.9 \pm 0.8$ \\
\hline $\mathrm{q}(\mathrm{mg} / \mathrm{g}) \beta$-Lactoglobulin & $24.1 \pm 0.8$ & $11.5 \pm 0.8$ \\
\hline Error $(\%)$ & $27.7 \pm 0.2$ & $19.35 \pm 1.3$ \\
\hline Removal efficiency $(\%)$ predicted & 15.2 & 6.8 \\
\hline Removal efficiency $(\%)$ validated & $81 \pm 0.5$ & $57 \pm 1.8$ \\
\hline Removal efficiency $(\%)$ Mixed & $78 \pm 1.4$ & $37 \pm 1.6$ \\
\hline Removal efficiency $(\%)$ & $90 \pm 1.2$ & $62 \pm 2.1$ \\
\hline -Lactoglobulin & 19 & 5 \\
\hline Error $(\%)$ & &
\end{tabular}

However, these results also showed that WPF had a better affinity to mercury than chromium, which is due to the chemical interactions and the intermolecular forces between the functional groups of WPF with heavy metals [44]. In this study, the adsorption capacity and removal efficiency of WPF for $\mathrm{Hg}$ and $\mathrm{Cr}$ were evaluated at $\mathrm{pH} 3$, which is a critical operating parameter to determine the interaction between metal ions and WPF due the solution $\mathrm{pH}$ can change the physicochemical properties of WPF and metal ions. The surface charge of WPF is affected by the $\mathrm{pH}$ and also it influences the way as the metal ion is presented in the solution, as $\mathrm{Hg}$ that is presented as a free cation and $\mathrm{Cr}$ is presented as a complex anion $\left(\mathrm{HCrO}_{4}{ }^{2-}\right)$ at $\mathrm{pH} 3$ [45]. Taking into consideration that the isoelectric point of $\beta$-Lactoglobulin amyloid fibrils is approximately 5.1 [46], the surface charge of WPF was positively charged at the evaluated conditions leading an electrostatic interaction between $\mathrm{HCrO}_{4}{ }^{2-}$ and WPF. On the other hand, $\mathrm{Hg}^{2+}$ is classified as a soft ion according to the HSAB theory, which means that it forms very strong bonds with $-\mathrm{SH},-\mathrm{SR},-\mathrm{CN},-\mathrm{NH}_{2}$ and imidazole groups containing nitrogen and sulfur atoms [47]. As consequence, WPF are composed by amide group and cysteines that have a high affinity for $\mathrm{Hg}$. A high presence of sulfur bonds due to the cysteine of whey proteins, such as the four disulfide bonds of $\alpha$-lactalbumin (Cys6-Cys120, Cys61-Cys77, Cys73-Cys91, and Cys28-Cys111) [48] and the sulfur of the Cys121 of $\beta$-Lactoglobulin, make WPF promising for $\mathrm{Hg}$ removal. Various researchers have confirmed that the Cys121 of $\beta$-Lactoglobulin at low $\mathrm{pH}$ has high affinity for cations such as $\mathrm{Hg}^{2+}$ and $\mathrm{Cd}^{2+}[49]$.

The model used in this study to obtain the best conditions to produce WPF predicted a $100 \%$ for the removal of $\mathrm{Hg}$, but a maximum removal efficiency of $81 \%$ was obtained experimentally using an initial $\mathrm{Hg}$ concentration of $50 \mathrm{mg} / \mathrm{L}$. This was due to the preparation conditions affected the way 
as whey protein aggregated into WPF because temperature and heating time impacted the degree of unfolding and, in consequence, the available sites and surface energy to adsorb metal ions [42]. As $\beta$-lactoglobulin unfolds to form amyloid fibrils, several peptides participate in fibril formation, and cys-121 is one of them [16]. So that, there are adsorption limits that the model at tested conditions does not consider and there was an error of $19 \%$ between predicted and experimental values of the removal efficiency [50]. It can be concluded that WPF is a promissory material to remove mercury considering its removal efficiency was $81 \%$, which compared with $\beta$-Lactoglobulin that had a removal efficiency of $90 \%$, the cost-effective performance is outstanding.

The results indicated that the best operational conditions produced WPF to remove the maximum quantity of mercury and chromium alone and mixed. Similar conditions (i.e., $75 \sim 120{ }^{\circ} \mathrm{C}, \mathrm{pH} \mathrm{2} \mathrm{3.5,}$ low salt content $<0.1 \mathrm{M}$ and $60 \sim 85{ }^{\circ} \mathrm{C}$, pH 2) are commonly used to form amyloid fibrils of $\beta$-Lactoglobulin $[29,41,51,52]$ and $\alpha$-lactalbumin $[48,53,54]$, respectively. Loveday et al. [55] concluded that a protein sequence exposed to different conditions can generate a variety of a fibrillar aggregations. These findings are in agreement with this work even when there is a variety of proteins interacting on whey protein, they can form active aggregates at the adequate conditions to remove heavy metals. In this study, this type of aggregates, named as WPF, presented an adsorption capacity of $24 \mathrm{and} 18 \mathrm{mg} / \mathrm{g}$ for chromium and mercury removal using $50 \mathrm{mg} / \mathrm{L}$ of initial concentration, respectively, see Table 3 . Then, an adsorption capacity of 27 and $19 \mathrm{mg} / \mathrm{g}$ was obtained for $\mathrm{Hg}$ and $\mathrm{Cr}$ using $\beta$-lactoglobulin fibrils as reference. There was not a significant difference between the adsorption capacity obtained for chromium using WPF and $\beta$-lactoglobulin fibrils, while the adsorption capacity to remove mercury using WPF and $\beta$-lactoglobulin only differed by $8 \%$ making this type of aggregates of whey promissory to remove toxic metal ions. Similarly, Zhang et al. [56] produced $\beta$-lactoglobulin nanofibrils at $90{ }^{\circ} \mathrm{C}$, $5 \% w / v, \mathrm{pH} 12$ for $10 \mathrm{~h}$, which were used to remove $\mathrm{Pb}$ with a maximum adsorption capacity of $212 \mathrm{mg} / \mathrm{g}$. This result demonstrates the high potential of protein nanofibers to remove heavy metals from water.

Adsorption capacities of 24.13 and $11.55 \mathrm{mg} / \mathrm{g}$ for mercury and chromium in a mixed solution (see Table 3) confirmed that WPF had more affinity for mercury. Note that mercury has a strong affinity to the functional groups of $\left(-\mathrm{NH}_{2}\right)$ [57] and $(-\mathrm{COOH})$ of the $\mathrm{R}$ group of amino acids, causing that the groups alpha amino and carboxyl are involved in the peptide bonds of the proteins and cannot interact with metal ions [58]. Additionally, the presence of cysteine and methionine in whey proteins promotes affinity from WPF to mercury though deprotonated thiol group [59], and also the deprotonation of tyrosine may generate a ligand to $\mathrm{Hg}$ [44]. However, the results showed that chromium was adsorbed also in the mixed solution. Thus, it means that functional groups of proteins like amine [60] and hydroxyl groups [61] favor the chromium adsorption, which is well known that these functional groups have an electrostatic effect on chromium adsorption. It can be concluded that WPF show specificity for mercury due to the interactions between the functional groups of whey proteins and metal ion $\operatorname{Hg}[5,62]$.

\subsection{Characterization of Protein Fibrils and Hybrid Membranes}

\subsubsection{AFM Characterization of Whey Protein Aggregates}

AFM characterization showed the transformation of native $\beta$-lactoglobulin and whey protein into aggregates at the best conditions to remove heavy metals ( $3.8 \% \mathrm{wt}, 74{ }^{\circ} \mathrm{C}$ for $7 \mathrm{~h}$ ) (see Figure 1 ). In particular, Figure 1A,B shows the morphology and height distribution of $\beta$-lactoglobulin as $5 \mathrm{~nm}$, which was similar with the height between $4-10 \mathrm{~nm}$ reported in the literature $[30,40,63,64]$. The difference of diameter in fibrils varies due to the denaturation conditions of the proteins, such as monomer concentration, temperature and incubation time, which led to protofilaments that form twisted fibrils from one protofilament until three filaments twisted [43]. 

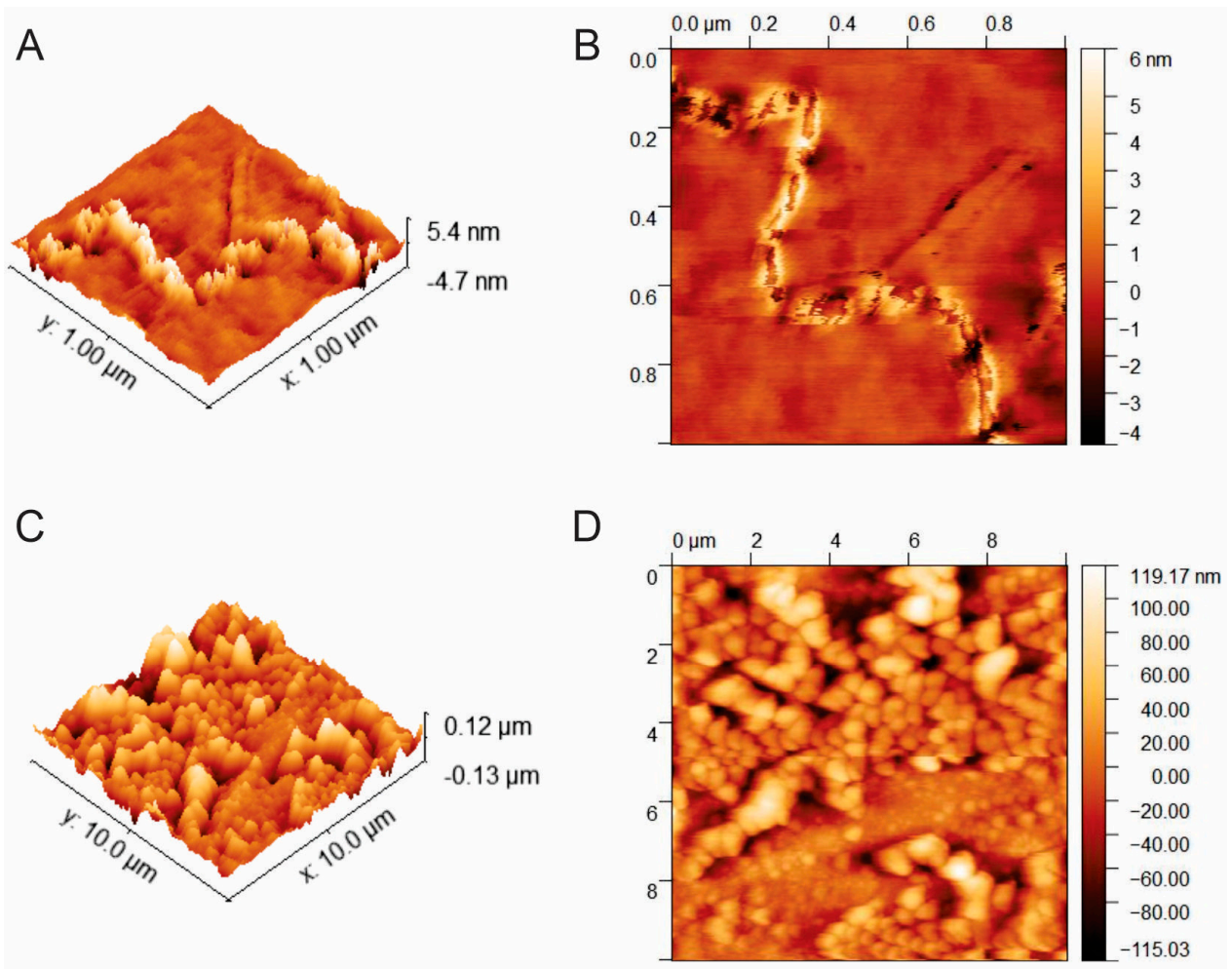

Figure 1. Morphological analysis of whey fibrils compared with $\beta$-lactoglobulin fibrils by AFM. (A) 3D reconstruction of AFM image of $\beta$-lactoglobulin fibrils; (B) image of morphology of $\beta$-lactoglobulin fibrils; (C) 3D reconstruction of AFM image of whey protein aggregates; (D) image of morphology of whey protein aggregates.

On the other hand, Figure 1C,D shows the aggregation of native whey at the best conditions to remove $\mathrm{Hg}$ and $\mathrm{Cr}$. The height of aggregates was $13 \mathrm{~nm}$, which was in agreement with the diameter of 5-15 $\mathrm{nm}$ reported in the literature for whey fibrils aggregates [65-67]. In addition, the height of whey protein aggregates is higher than $\beta$-lactoglobulin aggregates because whey protein aggregates at smaller rate than $\beta$-lactoglobulin due to $\alpha$-lactalbumin aggregates slower when heated than $\beta$-lactoglobulin [65]. Many authors confirmed the conversion of whey proteins onto fibrils aggregates at similar conditions evaluated in this work because binary mixtures of proteins with $\beta$-lactoglobulin tend to arrange as fibrils at the suitable denaturation conditions. For example, Bolder et al. [39] confirmed the aggregation of whey onto long semi-flexible fibrils by TEM. A recent study by Farrokhi et al. [66] demonstrated the fibrillation of whey by AFM via the heating of a solution of $2 \%$ of WPI at $80^{\circ} \mathrm{C}$ and $\mathrm{pH} 2$. They concluded that aggregates height did not change significantly with temperature and the aggregates presented a relative height distribution of $10 \mathrm{~nm}$ [66]. There are numerous reports that confirm the conversion of native whey at similar conditions of this report into fibril aggregation, which is an indicator that the aggregates obtained in the present study may be arranged as fibrils $[52,63,66,68]$.

\subsubsection{SEM Characterization of Hybrid Membrane of Whey Protein and Activated Carbon}

The image of hybrid membrane surface obtained by scanning electron microscopy (SEM) is shown in Figure 2A and the visual aspect of the membrane without magnification is given in Figure 2D, which was prepared with a mixture of 2:1 of WPF and AC by vacuum filtration. To take advantage of the properties of WPF and avoid agglomeration, WPF were adsorbed into AC to increase the mechanical properties and surface area of the WPF to remove heavy metal ions more efficiently.

Figure 2A,C shows the characteristic morphology of activated carbon and the transversal section of the membrane had a thickness of $\sim 100 \mu \mathrm{m} \pm 10$, which is a film thinner than the membrane reported by Peydayesh et al. [18], who prepared a hybrid membrane of $\beta$-lactoglobulin amyloid fibrils and 
activated carbon with a thickness of $1 \mathrm{~mm}$. Consequently, the fact of having a thinner membrane makes that the cross flow of water passes more easily through it. Additionally, the membrane reported in Figure 2D demonstrated to be a rigid film that was sufficiently strong to be handled without disassembling. The same result was found by Li et al. [32] in the preparation of a hybrid membrane of $\beta$-lactoglobulin fibrils and graphene oxide showing the robustness of the membrane cutting it with normal scissors [32]. In contrast, hybrid membranes elaborated with just AC demonstrated to be fragile because it disassembled easily to the touch.
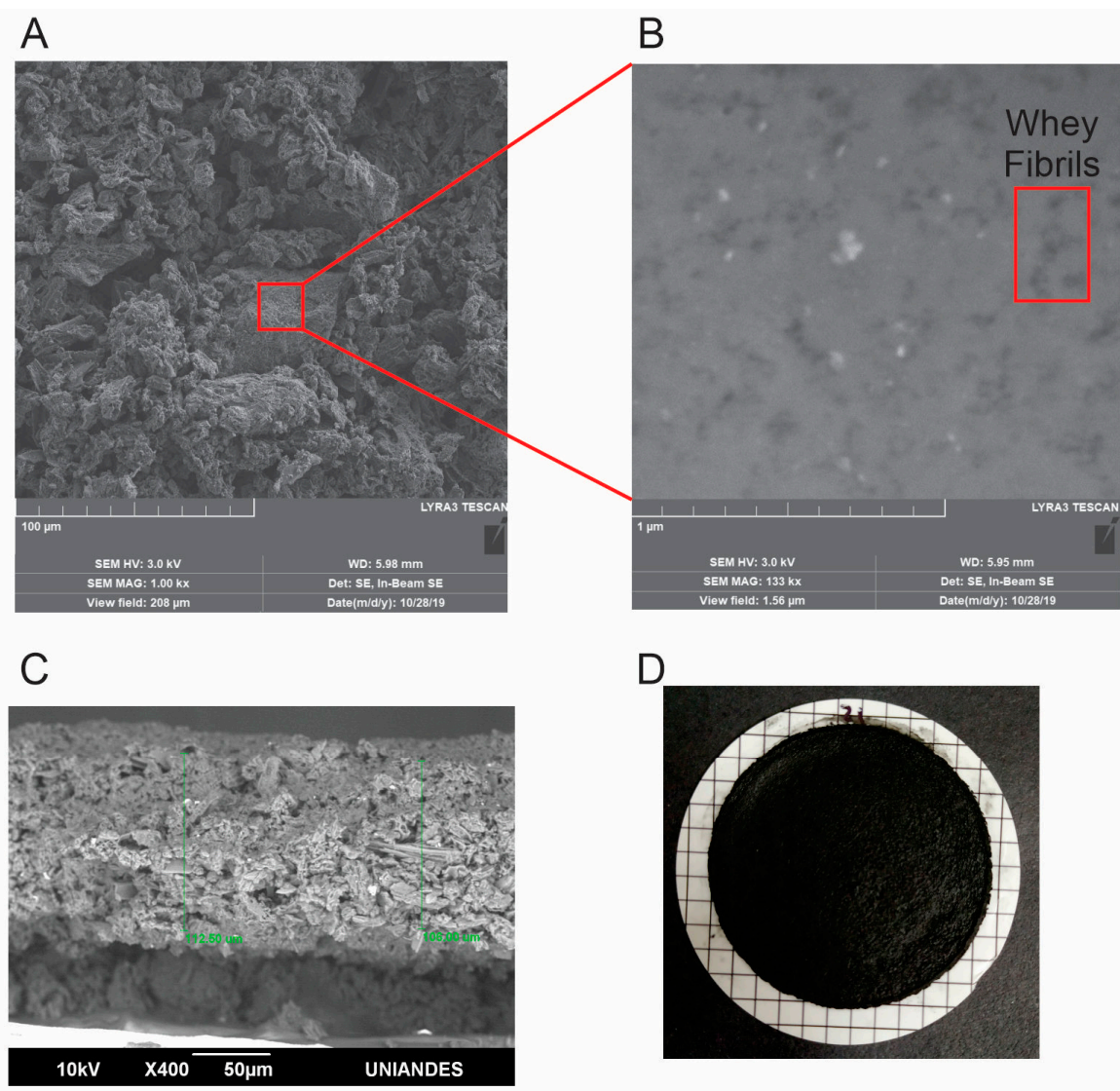

Figure 2. Morphological analysis of hybrid membrane of WPF and AC by SEM. (A) Image of the surface of the hybrid nanomembrane; $(\mathbf{B})$ higher magnification $(100 \times)$ of the SEM image of the hybrid membrane, showing in a circle the amyloid WPF adhered to the activated carbon; (C) SEM image of the transversal section of the membrane; (D) visual aspect of the membrane.

Furthermore, Figure 2B shows a higher magnification of the hybrid membrane $(1.5 \mu \mathrm{m})$, which confirms that amyloid WPF were adsorbed and adhered on the surface of AC thus demonstrating the formation of a uniform hybrid composite. SEM images indicated that WPF were highly adsorbed to the activated carbon surface as $\beta$-lactoglobulin fibrils reported by Bolisetty and Mezzenga [16]. In this way, it can be concluded that WPF can be used to elaborate hybrid membranes avoiding the purification of the $\beta$-lactoglobulin to obtain high-quality hybrid composites.

\subsubsection{Red Congo}

Dyeing with congo red (CR) is a method to characterize amyloid fibrillation, which depending on the state of protein aggregation, this dye binds to amyloid fibrils. CR binds to sites parallel and antiparallel to the fibril axis, and antiparallel and parallel, respectively, to the $\beta$-sheets on fibrils [34]. To determine the presence of amyloid fibrils by this method, the binding between CR and $\beta$-sheet structures is expected to cause an increase in the absorption from approximately 490 (unbound) to $510 \mathrm{~nm}$ (bound), with a bathochromic shift in its characteristic absorption spectrum [69]. 
The results of Figure $3 \mathrm{~A}$ show the spectra of native whey protein without heat treatment (as control) at different concentrations (0.5-5\%), which had a maximum absorbance at $490 \mathrm{~nm}$. In contrast, Figure 3B shows the whey protein spectra at different concentrations after heat treatment to analyse the amyloid formation. These results demonstrated that concentrations between 0.5 and $2 \%$ almost had no effects on the absorbance spectra, but concentrations of 3-4\% showed an absorption maximum at $505 \mathrm{~nm}$. Whey protein at 5\% showed a significant shift from 490 to $515 \mathrm{~nm}$, showing the formation of maximum amyloid fibrils at this concentration. These changes in absorbance are due to CR gets trapped into the cluster of $\beta$-sheet peptide backbone of the aggregates of $\beta$-lactoglobulin and $\alpha$-lactalbumin [70].
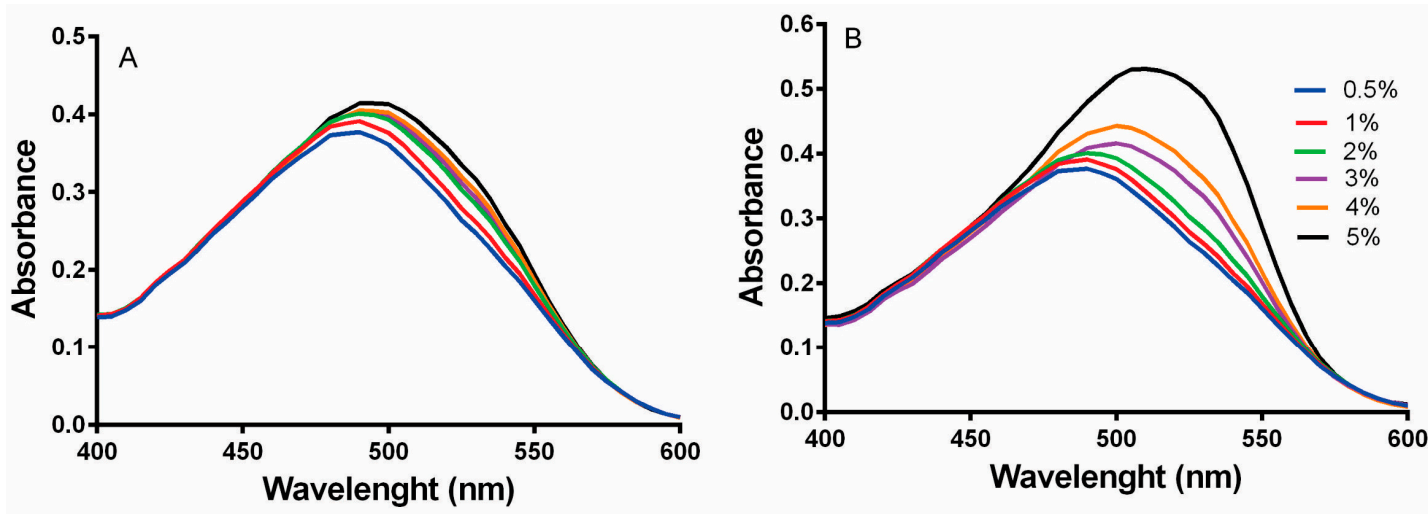

Figure 3. Congo red absorption spectra: (A) CR spectra for native whey protein at different concentrations (0.5-5\%); (B) CR spectra for amyloid WPF at different concentrations after heat treatment. The absorption spectra were recorded from 400 to $600 \mathrm{~nm}$.

These results indicated that a significant change in the absorbance spectra was observed at concentrations higher than 3\%, which demonstrated that whey solutions from this concentration after heat treatment aggregated into amyloid fibrils. The same trend was observed by Bolder et al. [39] and Veerman [38] where it has been stated that the increase of conversion of whey into aggregates is due to the increase of the total protein concentrations [38], and that the conversion strongly increases for WPI concentrations exceeding 3\% (w/w) [39]. Furthermore, Nicolai et al. [65] observed that large aggregates were formed a low $\mathrm{pH}$ and if a very small fraction of native proteins was depleted and the fraction of aggregates increased becoming more stable with the increase of protein concentration [65]. This method is also a confirmation that the aggregates obtained in this work were arranged as amyloid fibrils.

\subsubsection{FTIR}

FTIR spectra of hybrid materials at different composition of AC and WPF as well as pure WPF and AC are shown in Figure 4. The results demonstrated that different compositions of WPF and AC exhibited a change on the functional groups of the hybrid composites, which showed characteristic bands of AC and WPF. Consequently, WPF and the hybrid composite with 1:5 of AC and WPF presented a clear intensity variation in the typical amide region between 1300 and $1700 \mathrm{~cm}^{-1}$. Note that the band at $1615 \mathrm{~cm}^{-1}$ is a characteristic of primary amide group $(\mathrm{C}=\mathrm{O}, \mathrm{C}-\mathrm{N})$ and the band at $1530 \mathrm{~cm}^{-1}$ represents the secondary amide group $(\mathrm{N}-\mathrm{H}, \mathrm{C}-\mathrm{N})$ related to peptide bonds $(\mathrm{CO}-\mathrm{NH})$ of whey proteins [71]. Additionally, a decrease of intensity or disappearance of the amide bands in the hybrid composites with 1:2, 1:1 and 2:1 of WF and AC was related to the decrease of protein content due to the reduction of the proportion of WPF in these materials.

Moreover, all spectra presented a band at $3400 \mathrm{~cm}^{-1}$ that in the case of WPF it corresponds to stretching vibrations of $-\mathrm{OH}$ linked to $-\mathrm{NH}_{2}$ [72], and it can be also attributed to a hydroxyl group associated to phenols and alcohols for AC and hybrids [73]. All hybrid composites and AC presented bands at 2908 and $2810 \mathrm{~cm}^{-1}$ that correspond to $\mathrm{C}-\mathrm{H}$ aliphatic vibrations, which are assigned to asymmetric $\mathrm{CH}$ and symmetric $\mathrm{CH}$ bands, respectively, that are related to alkyl groups [74]. Activated carbon and 1:2 hybrid (WPF:AC) spectra showed bands at 3400, 2900, 1550 and $1087 \mathrm{~cm}^{-1}$ that are 
related to phenols, alcohols, aliphatic and aromatic rings that are typical bands of activated carbons synthesized at high carbonization time and temperature [75].

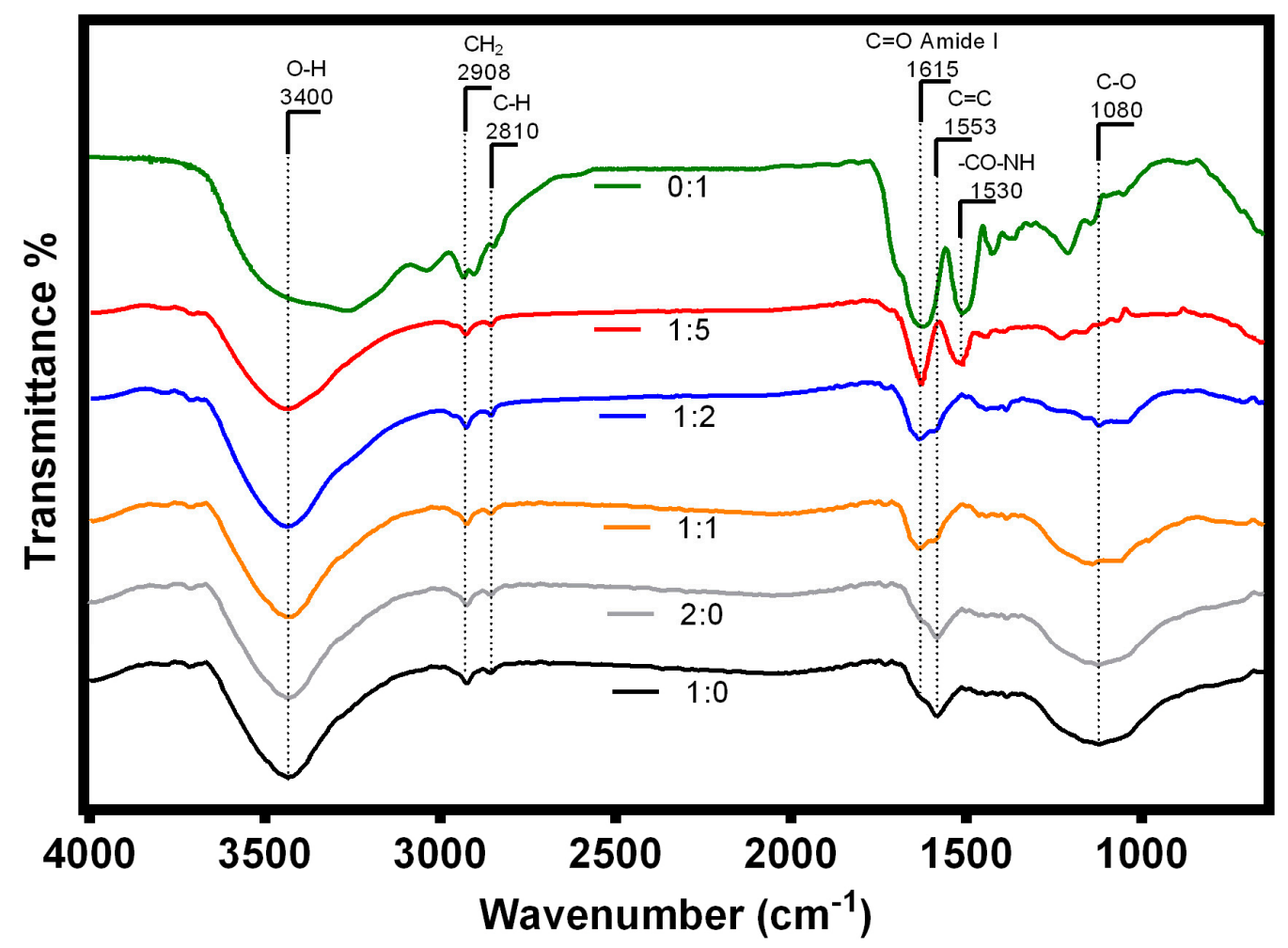

Figure 4. FTIR spectra of hybrid composites with different compositions of activated carbon (AC) and whey fibrils (WF) with respect to whey fibrils alone (green line) and pure activated carbon (black line).

The presence of the bands between 1000 and $1380 \mathrm{~cm}^{-1}$ in the WPF corresponds to $\mathrm{C}-\mathrm{O}, \mathrm{C}-\mathrm{C}$ and $\mathrm{C}-\mathrm{OH}$ groups [72] that were the ones that became less defined when the content of $\mathrm{AC}$ increased in the hybrid composite. Also, the increment of AC content into the hybrid was associated to the band at $1080 \mathrm{~cm}^{-1}$ that corresponds to $\mathrm{C}-\mathrm{O}$ stretching of secondary hydroxyl group, that is well defined in the AC spectra [75]. It may be concluded that WPF were adsorbed into AC where the main changes of hybrid composites spectra in relation with pure WPF and AC were in the region between 900 and $1700 \mathrm{~cm}^{-1}$, so that the main changes are related to the functional group of amide for WPF and C-O bonds for AC. A similar behaviour was reported by Torres et al. [76] that described the immobilization of soybean peroxidase into activated carbon where there was a displacement of the band at $1580 \mathrm{~cm}^{-1}$ and an overlapping of the $\mathrm{C}=\mathrm{O}$ band of the backbone of peptide bonds with the $\mathrm{N}-\mathrm{H}, \mathrm{C}-\mathrm{N}$ and $\mathrm{C}=\mathrm{C}$ vibrations.

The results of this study demonstrated that the hybrid composites of WPF and AC presented functional groups of both components suggesting that WPF and AC interacted chemically by amide group and $\mathrm{C}-\mathrm{O}$ bonds, but also there were physical interactions as hydrophobic forces that include electrostatic, van der Waals, steric and solvation forces carried by amino acids and their polypeptide chain that interacted with AC $[77,78]$. These findings are consistent with the results presented by Li et al. [32]. These authors identified similar patterns in the FTIR spectrum using composites prepared with amyloid fibrils of $\beta$-lactoglobulin and graphene [32]. Consequently, the hybrid composite selected to prepare the hybrid membrane was the hybrid with 1:2 of AC and WPF, which has the band at $1615 \mathrm{~cm}^{-1}$ that represents the amide group demonstrating the presence of the peptide bonds of proteins. This means that WPF were adsorbed into $\mathrm{AC}$ and its active groups (i.e., $-\mathrm{SH},-\mathrm{OH}$ and $-\mathrm{NH} 2$ and -COOR of the R group of amino acids) may be present in the hybrid membrane to remove heavy metals. 
The group - $\mathrm{OH}$ and secondary alcohol presented in $\mathrm{AC}$ part of the hybrid can also interact with metal ions [79].

\subsubsection{BET Surface Area}

BET surface area of AC and hybrid composites with different compositions of WPF and AC are shown in Figure 5. The surface area of AC decreased as WPF content in the composite increased, which resulted in an enhancement of the surface area of WPF, thus preventing the agglomeration between them. This is the reason why, at greater quantities of WPF, these adhered to the active empty sites of activated carbon and created a hybrid composite with the features of AC and WPF. Similar findings were observed by Li et al. [32] that characterized a graphene-amyloid fibril ( $\beta$-lactoglobulin) composite and concluded that amyloid fibrils were adsorbed onto graphene due to charged amyloid fibrils generated an overall surface charge density. They also concluded that when the amount of amyloid fibrils increased, the graphene became more stable in water due to the surface activity of fibrils [32]. Likewise, Andrade et al. [77] studied the adsorption of $\beta$-lactoglobulin on AC at $\mathrm{pH} 3$ and they found that the maximum amount of $\beta$-lactoglobulin was adsorbed on $\mathrm{AC}$ at this $\mathrm{pH}$ value. However, the $\mathrm{pH}$ of point zero charge of $\mathrm{AC}$ was 6 and the isoelectric point of the protein was 5.2 meaning that both were positively charged at these conditions [77]. Additionally, the maximum adsorption of $\beta$-lactoglobulin with $\mathrm{AC}$ was carried out at $\mathrm{pH} 3$ in accordance with this study, which was carried out at $\mathrm{pH} 2$. In this case, the hydrophobic forces between the amino acids and $\mathrm{AC}$ were the driving forces that led to a potential hybrid composite with the properties of WPF and AC, thus allowing the preparation of a hybrid membrane for the removal of heavy metal ions from water $[78,80]$.

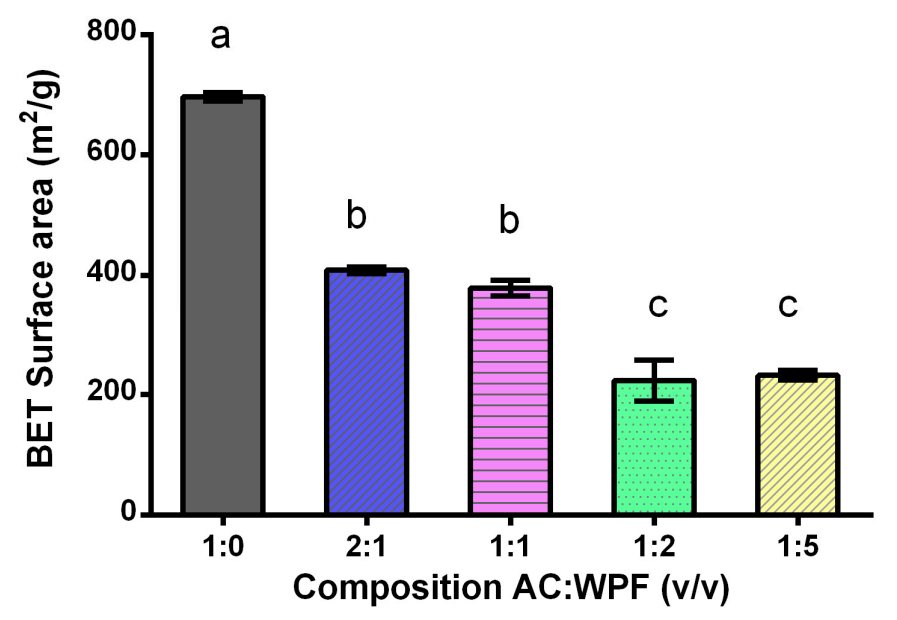

Figure 5. BET surface area of different mixtures of AC and WPF. Error bars are standard deviations $(n=3)$. Different letters on the bars indicate significant differences between different treatments at $p$-level $=0.05$ based on the least significant difference (LSD) test.

Figure 5 shows that the mixtures 2:1 and 1:1 of AC and WPF had a surface area of $\sim 400 \mathrm{~m}^{2} / \mathrm{g}$, and the maximum WPF adsorbed on AC leaded to a surface area of $\sim 240 \mathrm{~m}^{2} / \mathrm{g}$ using the compositions 1:2 and 1:5 (AC:WPI). From this, it may be concluded that the composition 1:2 was the best mixture to elaborate the hybrid membrane because it was the condition were the AC was saturated with WPF. Therefore, the mixture 1:5 did not have a decrease in its BET area owing to the maximum quantity of fibres adsorbed, leaving fibres in the aqueous medium without being used. The same was observed by Li et al. [32], who identified by TEM a mixture of 1:5 of graphene and $\beta$-lactoglobulin fibres left fibre free in the media. Even though, it is well known that materials with a large surface area are good adsorbents, the objective of introducing WPF into AC was to functionalize AC so that the hybrid can compensate the physisorption of the AC with the chemisorption effect of WPF [16]. The hybrid composite from the mixture 1:2 demonstrated to be sufficiently strong to adhere and cover the hole 
surface of the nitrocellulose membranes by vacuum filtration without disassembling, which was due to the quantity of highly-adherent WPF adsorbed onto AC.

\subsection{Removal Efficiency of Heavy Metals}

The adsorption capacities for batch filtration adsorption of mercury and chromium at 25, 50 and $100 \mathrm{mg} / \mathrm{L}$ using a hybrid membrane of WPF and AC are shown in Figure 6. Note that membranes with WPF and AC alone were also analysed as references. As it can be noted, the adsorption capacities for mercury removal were $5.20,12.14$ and $14.85 \mathrm{mg} / \mathrm{g}$ at initial $\mathrm{Hg}$ concentrations of 25,50 and $100 \mathrm{mg} / \mathrm{L}$, respectively (Figure 6). The adsorption capacities for the hybrid membrane at 25 and $50 \mathrm{mg} / \mathrm{L}$ were significantly different to the results obtained by the membranes of WPF and AC alone. This could be due to the synergistic effect of the AC and the WPF because both materials created a balance between the porosity of the membrane and the operating water processing flow rate [16]. It can explain that the membranes of WPF alone showed agglomerations of fibrils that were fixed on the surface of the cellulose membrane by the hydrophobic character of WPF and it did not allow an efficient mass transport on the membrane.

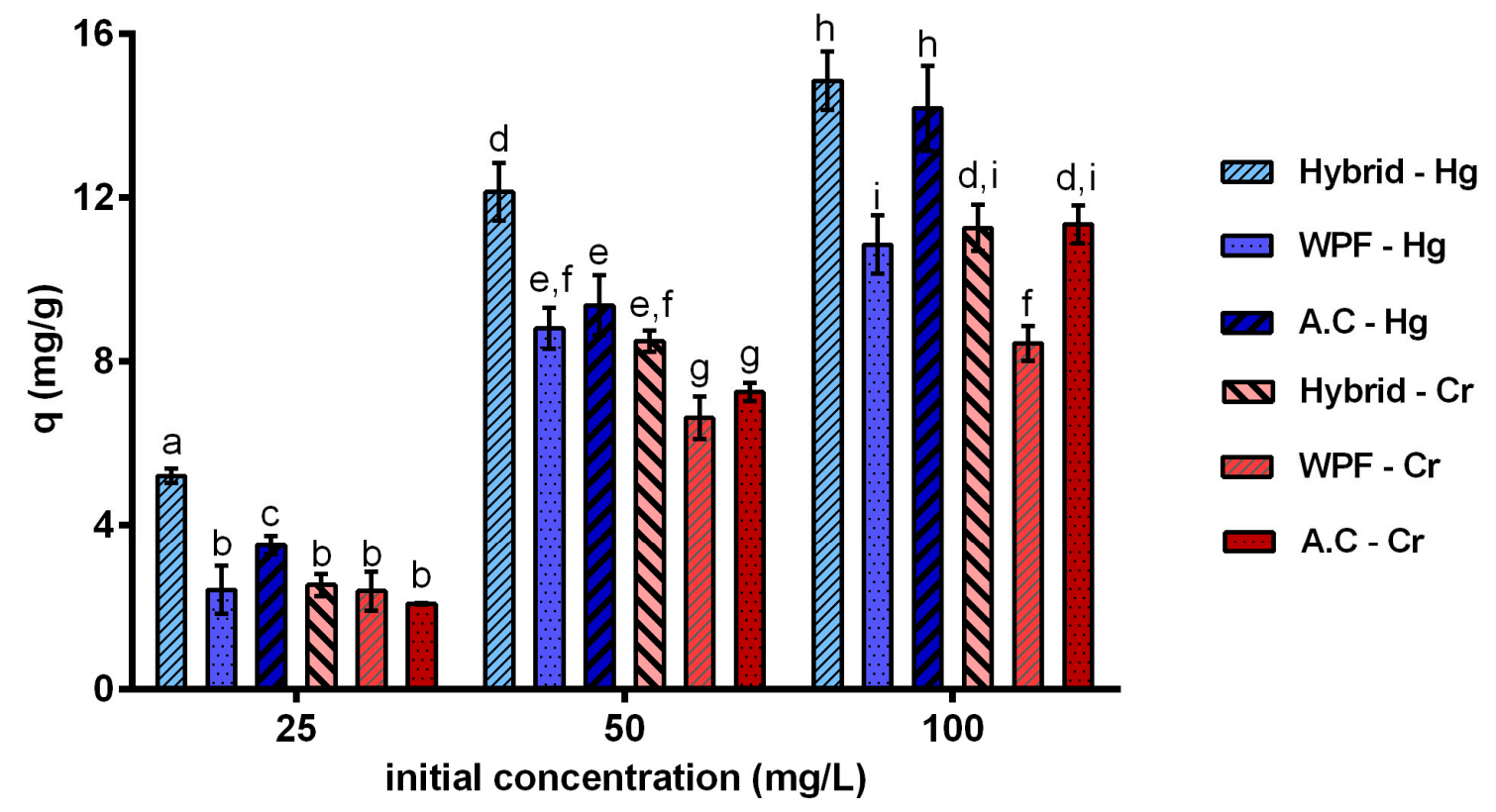

Figure 6. Adsorption capacity of membranes of AC, WPF and the Hybrid of 1:2 AC:WPF for mercury (blue bars) and chromium (red bars) at initial concentrations of 25, 50 and $100 \mathrm{mg} / \mathrm{L}$. Error bars are standard deviations $(n=3)$. Different letters on the bars indicate significant differences between different treatments at $p$-level $=0.05$ based on the least significant difference (LSD) test.

The adsorption capacity of the hybrid membrane was $14.85 \mathrm{mg} / \mathrm{g}$ for mercury at initial concentration of $100 \mathrm{mg} / \mathrm{L}$, which was a higher value regarding to the adsorption capacity of 10.61 and $9.61 \mathrm{mg} / \mathrm{g}$ reported by Bolisetty and Mezzenga [16] using a hybrid membrane made of $\beta$-Lactoglobulin and a hybrid membrane of melanin-coated with PVDF, respectively, see Table 4. However, Razmi et al. [81] obtained an adsorption capacity of $77 \mathrm{mg} / \mathrm{g}$ to remove mercury using a hybrid membrane of eggshell protein with reduced graphene oxide, which presented a higher adsorption capacity due to the functional groups, high surface volume ratio and uniform distribution of the reduced graphene oxide [81]. From this analysis, it can be inferred that the hybrid membrane of whey protein fibrils is even more efficient as one made of just pure $\beta$-Lactoglobulin, but it can also be improved by changing the support of the WPF by reduced graphene oxide or using other types of adsorbent. 
Table 4. Metal adsorption capacity of some bio-based hybrid membranes reported in literature.

\begin{tabular}{|c|c|c|c|c|c|}
\hline Hybrid Membrane & Heavy Metal & $q(\mathrm{mg} / \mathrm{g})$ & Evaluation & $\begin{array}{c}\text { Co } \\
(\mathrm{mg} / \mathrm{g})\end{array}$ & Ref \\
\hline \multirow{4}{*}{$\begin{array}{l}\text { Hybrid membrane } \\
\text { AC-B-lactoblogulin }\end{array}$} & $\mathrm{Au}$ & 52.5 & \multirow{4}{*}{ 1st Cycle } & 561 & \multirow{4}{*}{ [16] } \\
\hline & $\mathrm{Hg}$ & 10.6 & & 85 & \\
\hline & $\mathrm{Pb}$ & 995.7 & & 65 & \\
\hline & $\mathrm{Pd}$ & 356.6 & & 12 & \\
\hline $\begin{array}{l}\text { Eggshell membrane protein } \\
\text { doped with reduced } \\
\text { graphene oxide }\end{array}$ & $\mathrm{Hg}$ & 77 & 1st Cycle & 0.01 & [81] \\
\hline \multirow{2}{*}{$\begin{array}{l}\text { Hybrid membrane } \\
\text { AC-B-lactoblogulin }\end{array}$} & Arsenate & 0.2 & \multirow{2}{*}{ 1st Cycle } & \multirow{2}{*}{0.2} & \multirow{2}{*}{ [17] } \\
\hline & Arsenite & 1.1 & & & \\
\hline $\begin{array}{l}\text { Hybrid membrane of } \\
\text { lignin/nylon- } 6 \text { membrane and } \\
\text { oats/nylon- } 6 \text { membrane }\end{array}$ & $\mathrm{Pb}$ & 37 and 11 & Batch for $2 \mathrm{~h}$ & 10 & [82] \\
\hline \multirow{6}{*}{$\begin{array}{l}\text { Hybrid membrane of silk } \\
\text { nanofibril (SNF) and } \\
\text { hydroxyapatite (HAP) }\end{array}$} & $\mathrm{Au}$ & 135.7 & \multirow{6}{*}{ Batch for $48 \mathrm{~h}$} & \multirow{6}{*}{100} & \multirow{6}{*}{ [83] } \\
\hline & $\mathrm{Ag}$ & - & & & \\
\hline & $\mathrm{Cu}$ & 64.7 & & & \\
\hline & $\mathrm{Ni}$ & 63.0 & & & \\
\hline & $\mathrm{Cr}$ & 126.7 & & & \\
\hline & $\mathrm{Pb}$ & - & & & \\
\hline \multirow{4}{*}{$\begin{array}{l}\text { Hybrid membrane } \\
\text { AC-B-lactoblogulin }\end{array}$} & $\mathrm{Cr}$ & 148.6 & \multirow{4}{*}{ 1st Cycle } & 0.17 & \multirow{4}{*}[18]{} \\
\hline & $\mathrm{Ni}$ & 13.8 & & 0.21 & \\
\hline & $\mathrm{Ag}$ & 86.7 & & 0.20 & \\
\hline & $\mathrm{Pt}$ & 234.7 & & 0.13 & \\
\hline \multirow{2}{*}{$\begin{array}{l}\text { Graphene-Bovine Serum } \\
\text { Albumin Hybrid Membrane }\end{array}$} & Co & 0.5 & \multirow{2}{*}{ 1st Cycle } & \multirow{2}{*}{1000} & \multirow{2}{*}{ [2] } \\
\hline & $\mathrm{Cu}$ & 0.3 & & & \\
\hline \multirow{4}{*}{$\begin{array}{l}\text { Melanin-coated PVDF } \\
\text { membranes }\end{array}$} & $\mathrm{Hg}$ & 9.2 & \multirow{4}{*}{ 1st Cycle } & \multirow{4}{*}{3} & \multirow{4}{*}[84]{} \\
\hline & $\mathrm{Cr}$ & 5.0 & & & \\
\hline & $\mathrm{Pb}$ & 4.0 & & & \\
\hline & $\mathrm{Cu}$ & 6.9 & & & \\
\hline \multirow{2}{*}{ This study } & $\mathrm{Hg}$ & 14.8 & \multirow{2}{*}{ 1st Cycle } & \multirow{2}{*}{100} & \\
\hline & $\mathrm{Cr}$ & 11.2 & & & \\
\hline
\end{tabular}

Similarly, the results of the adsorption capacities for the hybrid membrane were $2.53,8.5$ and $11.26 \mathrm{mg} / \mathrm{g}$ to remove chromium at initial concentrations of 25,50 and $100 \mathrm{mg} / \mathrm{L}$. There was no significant evidence to claim that the adsorption capacities of the hybrid membrane were different from the membranes with WPF and AC alone. Yet, the hybrid membrane showed adsorption results as good as the results of a membrane made with commercial activated carbon alone, which demonstrated the high potential of this hybrid material for heavy metal removal. Note that Peydayesh et al. [18] reported an adsorption capacity for $\beta$-lactoglobulin of 5.7 times higher than activated carbon for chromium at $174 \mathrm{ppb}$ [18]. Additionally, the hybrid membrane of WPF and AC showed better removal for $\mathrm{Cr}$ than the hybrid membrane of melanin nanoparticles coated in polyvinylidene fluoride membrane obtained by Manirethan and Balakrishnan [84] (see Table 4). However, some of the bio-based hybrid membranes reported in the literature showed a better performance to remove $\mathrm{Cr}$, comparison to the hybrid membrane of this study, with adsorption capacities of 126.7 and $148.65 \mathrm{mg} / \mathrm{g}$ using a 
hybrid membrane of silk nanofibrils and hydroxyapatite [83] and a hybrid membrane of AC and $\beta$-lactoglobulin [18] at tested conditions. The high adsorption capacity of the hybrid membrane showed a superior performance compared with the results of this study due to silk nanofibrils and hydroxyapatite interact with metal ions through chelation and ion exchange, besides the favourable conditions of $\mathrm{pH}$ [83]. Furthermore, it is important to remark that the result of the adsorption capacity of the hybrid membrane of $\mathrm{AC}$ and $\beta$-lactoglobulin [18] with respect to the result obtained in this study are not comparable as the initial concentrations evaluated differ by 1000 times. However, the higher performance of the hybrid membrane of $A C$ and $\beta$-lactoglobulin could be due to the active functional groups of the isolated $\beta$-lactoglobulin [18]. In contrast, the adsorption capacities obtained in this study for mercury were higher than the adsorption capacities for chromium, which agreed with the results for WPF, which appears to have more affinity for the removal of mercury than chromium. These results confirmed the prominent role of WPF in the separation performance of these hybrid membranes [17]. Consequently, it opens the possibility to use WPF alone to elaborate hybrid membranes [56] to remove mercury, chromium and other heavy metals as is shown by other reports, based on the fact that some of the functional groups that work to remove $\mathrm{Hg}$ well may also work to remove other heavy metals, such as $\mathrm{Pb}$ [82], $\mathrm{Pd}$ [16] and As [17]. Additionally, it is possible to design other types of hybrid membranes using WPF to avoid the use of commercial AC [46].

The reusability of the hybrid membrane is shown in Figure 7 where $50 \mathrm{~mL}$ of a solution of $\mathrm{HgCl}_{2}$ (Figure 7A) and $\mathrm{Na}_{2} \mathrm{CrO}_{4}$ (Figure 7B) with an initial concentration of $50 \mathrm{mg} / \mathrm{L}$ were filtered by ten consecutive cycles with the same hybrid membrane. The results showed that the performance of the membrane was efficient beyond the ten cycles, but the adsorption capacities decreased as the number of filtering cycles increased. Note that these decrements of the removal performance were more significant for the hybrid membrane in comparison with the results obtained with an AC membrane. This phenomenon could be due to the impact of mass transfer phenomena on the adsorption mechanism due to textural parameters [85]. Reduction of metal adsorption could be the consequence of the decrease in $65 \%$ of the BET area of the hybrid material with respect to the AC membrane. Considering that $\mathrm{AC}$ has a large surface area due to the high number of micropores [86], the saturation of saturation of $\mathrm{AC}$ membrane requires more cycles than the hybrid material. However, the mercury removal of the hybrid membrane was still higher than the AC membrane due to the chemisorption effects and electrostatic interactions of the functional groups with high affinity for $\mathrm{Hg}$ [47]. Similar findings were reported by Bolisetty and Mezzenga [16]. These authors identified a high saturation capacity for a hybrid membrane of $\beta$-lactoglobulin through 10 filtering cycles for $\mathrm{KAu}(\mathrm{CN})_{2}, \mathrm{HgCl}_{2}, \mathrm{~Pb}\left(\mathrm{C}_{2} \mathrm{H}_{3} \mathrm{O}_{2}\right)_{4}$ and $\mathrm{Na}_{2} \mathrm{PdCl}_{4}$. Bolisetty et al. [17] stated that this type of membrane can be used for several cycles without its considerable saturation for arsenic removal. The same effect was also noted by different studies on the removal of chromium, nickel, silver, platinum and aluminum $[2,18]$.
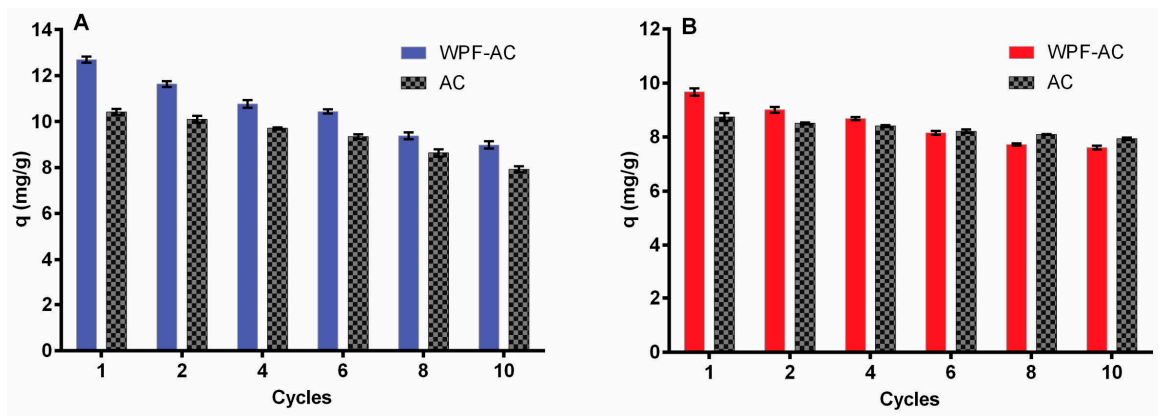

Figure 7. Comparison of the adsorption capacity per filtration cycle of the hybrid membrane and AC alone using adsorbate solutions with initial concentration of $50 \mathrm{mg} / \mathrm{L}$. (A) Adsorption capacity per cycle of filtration for mercury; (B) adsorption capacity per cycle of filtration for chromium. Error bars represent the standard deviations $(n=3)$. 


\section{Conclusions}

In this work, whey protein fibrils were produced by heat treatment and used to remove chromium and mercury from water. Results showed that the best conditions to produce WPF were $74^{\circ} \mathrm{C}, 7 \mathrm{~h}$ and $3.8 \%$ of whey protein, which demonstrated a better adsorption capacity for mercury than chromium in a mixed solution and alone. Removal studies confirmed the WPF affinity for mercury due to WPF having more active groups that interact with mercury in contrast with the electrostatic interactions between the positive charge of WPF and the negative charge of $\mathrm{HCrO}_{4}{ }^{2-}$. It has been demonstrated that the operational conditions to produce WPF as temperature, time and whey content have a critical effect on whey protein aggregation and, consequently, on the adsorption capacity of heavy metals. Consequently, WPF in combination with AC were used to produce a hybrid membrane, which, as confirmed by SEM, resulted in a high-quality, rigid and well-organized layered structures. FTIR and Red Congo assays led to the conclusion that the hybrid membrane obtained have the functional groups of AC and WPF and that the whey proteins of the membrane are arranged as amyloid fibrils, respectively. The hybrid membrane of WPF and AC efficiently removed mercury and chromium from water with adsorption capacities of 14.85 and $11.26 \mathrm{mg} / \mathrm{g}$ using batch vacuum filtration, supporting beyond ten filtration cycles. The performance of the removal of mercury and chromium is due to the synergistic effect of the chemisorption of the attracting functional groups of WPF by heavy metals and the physisorption of AC pores, which led to a hybrid membrane suitable for the removal of $\mathrm{Hg}$ and $\mathrm{Cr}$. The promissory performance of this hybrid membrane leads to the possibility of using the mixture of proteins like whey to produce fibre amyloids as a way to avoid the separation of $\beta$-lactoglobulin or other proteins from whey, which results in a lower cost production, and a convenient and quicker process. Furthermore, it is a way to give an application to whey that is a cheese byproduct.

Author Contributions: L.C.R.-R.: conceptualization, investigation, performed the experiments, writing-original draft under the supervision of C.J.-J.; L.E.D.B.: conceptualization, writing-review and editing; M.X.Q.-C.: microscopy conceptualization, writing-review and editing; D.I.M.-C.: conceptualization, writing-review and editing; A.B.-P.: conceptualization, writing-review and editing; C.J.-J.; project administration, conceptualization, methodology, funding acquisition, writing-review and editing. All authors have read and agreed to the published version of the manuscript.

Funding: This research was funded by Universidad de La Sabana under grant number GL 0843-ING 228-2019.

Acknowledgments: Authors gratefully acknowledge Martha Isabel Cobo Angel for the use of the ChemBET Pulsar TPR/TPD apparatus to carry out the BET area experiments. Additionally, the authors acknowledge Universidad de La Sabana for financial support. Laura Cristina Ramirez-Rodriguez would personally like to acknowledge the Universidad de La Sabana for the Teaching Assistant Scholarship for her master's studies.

Conflicts of Interest: The authors declare no conflict of interest.

\section{References}

1. Genthe, B.; Kapwata, T.; Le Roux, W.; Chamier, J.; Wright, C.Y. The reach of human health risks associated with metals/metalloids in water and vegetables along a contaminated river catchment: South Africa and Mozambique. Chemosphere 2018, 199, 1-9. [CrossRef] [PubMed]

2. Yu, X.; Sun, S.; Zhou, L.; Miao, Z.; Zhang, X.; Su, Z.; Wei, G. Removing Metal Ions from Water with Graphene-Bovine Serum Albumin Hybrid Membrane. Nanomaterials 2019, 9, 276. [CrossRef] [PubMed]

3. Alam, M.; Khan, M.; Khan, A.; Zeb, S.; Khan, M.A.; Amin, N.; Sajid, M.; Khattak, A.M. Concentrations, dietary exposure, and human health risk assessment of heavy metals in market vegetables of Peshawar, Pakistan. J. Environ. Monit. Assess. 2018, 190, 505. [CrossRef] [PubMed]

4. Azimi, A.; Azari, A.; Rezakazemi, M.; Ansarpour, M. Removal of Heavy Metals from Industrial Wastewaters: A Review. ChemBioEng Rev. 2017, 4, 37-59. [CrossRef]

5. Jin, X.; Wang, H.; Jin, X.; Wang, H.; Chen, L.; Wang, W.; Lin, T.; Zhu, Z. Preparation of keratin/PET nanofiber membrane and its high adsorption performance of Cr(VI). Sci. Total Environ. 2020, 710, 135546. [CrossRef]

6. Carolin, C.F.; Kumar, P.S.; Saravanan, A.; Joshiba, G.J.; Naushad, M. Efficient techniques for the removal of toxic heavy metals from aquatic environment: A review. J. Environ. Chem. Eng. 2017, 5, 2782-2799. [CrossRef] 
7. Liu, C.; Peng, J.; Zhang, L.; Wang, S.; Ju, S.; Liu, C. Mercury adsorption from aqueous solution by regenerated activated carbon produced from depleted mercury-containing catalyst by microwave-assisted decontamination. J. Clean. Prod. 2018, 196, 109-121. [CrossRef]

8. Burakov, A.E.; Galunin, E.V.; Burakova, I.V.; Kucherova, A.E.; Agarwal, S.; Tkachev, A.G.; Gupta, V.K. Adsorption of heavy metals on conventional and nanostructured materials for wastewater treatment purposes: A review. Ecotoxicol. Environ. Saf. 2018, 148, 702-712. [CrossRef]

9. Teh, C.Y.; Budiman, P.M.; Shak, K.P.Y.; Wu, T.Y. Recent Advancement of Coagulation-Flocculation and Its Application in Wastewater Treatment. Ind. Eng. Chem. Res. 2016, 55, 4363-4389. [CrossRef]

10. Luo, T.; Abdu, S.; Wessling, M. Selectivity of ion exchange membranes: A review. J. Memb. Sci. 2018, 555, 429-454. [CrossRef]

11. Rosa, M.A.; Egido, J.A.; Márquez, M.C. Enhanced electrochemical removal of arsenic and heavy metals from mine tailings. J. Taiwan Inst. Chem. Eng. 2017, 78, 409-415. [CrossRef]

12. Pan, L.; Wang, Z.; Yang, Q.; Huang, R. Efficient removal of lead, copper and cadmium ions from water by a porous calcium alginate/graphene oxide composite aerogel. Nanomaterials 2018, 8, 957. [CrossRef] [PubMed]

13. Elhafez, S.E.A.; Hamad, H.A.; Zaatout, A.A.; Malash, G.F. Management of agricultural waste for removal of heavy metals from aqueous solution: Adsorption behaviors, adsorption mechanisms, environmental protection, and techno-economic analysis. Environ. Sci. Pollut. Res. 2017, 24, 1397-1415. [CrossRef] [PubMed]

14. Khulbe, K.C.; Matsuura, T. Removal of heavy metals and pollutants by membrane adsorption techniques. Appl. Water Sci. 2018, 8, 1-30. [CrossRef]

15. Tamagawa, H.; Morita, S. Membrane potential generated by ion adsorption. Membranes 2014, 4, 257-274. [CrossRef]

16. Bolisetty, S.; Mezzenga, R. Amyloid-carbon hybrid membranes for universal water purification. Nat. Nanotechnol. 2016, 11, 365-371. [CrossRef]

17. Bolisetty, S.; Reinhold, N.; Zeder, C.; Orozco, M.N.; Mezzenga, R. Efficient purification of arsenic-contaminated water using amyloid-carbon hybrid membranes. Chem. Commun. 2017, 53, 5714-5717. [CrossRef]

18. Peydayesh, M.; Bolisetty, S.; Mohammadi, T.; Mezzenga, R. Assessing the Binding Performance of Amyloid-Carbon Membranes Towards Heavy Metal Ions. Langmuir 2019, 35, 4161-4170. [CrossRef]

19. Mezzenga, R.; Zhang, Q.; Bolisetty, S.; Cao, Y.; Handschin, S.; Adamcik, J. Selective and efficient removal of fluoride from water by in-situ engineered amyloid fibrils- $\mathrm{ZrO} 2$ hybrid membranes. Angew. Chem. Int. Ed. 2019, 58, 6012-6016.

20. Vega-Lugo, A.C.; Lim, L.T. Effects of poly(ethylene oxide) and $\mathrm{pH}$ on the electrospinning of whey protein isolate. J. Polym. Sci. Part B Polym. Phys. 2012, 50, 1188-1197. [CrossRef]

21. Bacenetti, J.; Bava, L.; Schievano, A.; Zucali, M. Whey protein concentrate (WPC) production: Environmental impact assessment. J. Food Eng. 2018, 224, 139-147. [CrossRef]

22. Guo, M.; Wang, G. Future Development of Whey Protein Production. In Whey Protein Production, Chemistry, Func- Tionality, and Applications; Guo, M., Ed.; Wiley: Hoboken, NJ, USA, 2019; pp. 251-260. ISBN 9781119256038.

23. Yver, A.L.; Bonnaillie, L.M.; Yee, W.; Mcaloon, A.; Tomasula, P.M. Fractionation of whey protein isolate with supercritical carbon dioxide-process modeling and cost estimation. Int. J. Mol. Sci. 2012, 13, 240-259. [CrossRef] [PubMed]

24. Menchik, P.; Moraru, C.I. Nonthermal concentration of liquid foods by a combination of reverse osmosis and forward osmosis. Acid whey: A case study. J. Food Eng. 2019, 253, 40-48. [CrossRef]

25. Jiang, B.; Wang, L.; Na, J.; Zhang, X.; Yuan, Y.; Liu, C.; Feng, Z. Environmentally-friendly strategy for separation of $\alpha$-lactalbumin from whey by aqueous two phase flotation. Arab. J. Chem. 2020, 13, 3391-3402. [CrossRef]

26. Wen-qiong, W.; Yun-chao, W.; Xiao-feng, Z.; Rui-xia, G.; Mao-lin, L. Whey protein membrane processing methods and membrane fouling mechanism analysis. Food Chem. 2019, 289, 468-481. [CrossRef]

27. Alhashimi, H.A.; Aktas, C.B. Life cycle environmental and economic performance of biochar compared with activated carbon: A meta-analysis. Resour. Conserv. Recycl. 2017, 118, 13-26. [CrossRef]

28. Gago, D.; Chagas, R.; Ferreira, M.; Velizarov, S.; Coelhoso, I. A Novel Cellulose-Based Polymer for Efficient Removal of Methylene Blue. Membranes 2020, 10, 13. [CrossRef]

29. Loveday, S.M.; Anema, S.G.; Singh, H. $\beta$-Lactoglobulin nanofibrils: The long and the short of it. Int. Dairy J. 2017, 67, 35-45. [CrossRef] 
30. Bolder, S.G.; Hendrickx, H.; Sagis, L.M.C.; Van Der Linden, E. Fibril assemblies in aqueous whey protein mixtures. J. Agric. Food Chem. 2006, 54, 4229-4234. [CrossRef]

31. Zare-Dorabei, R.; Ferdowsi, S.M.; Barzin, A.; Tadjarodi, A. Highly efficient simultaneous ultrasonic-assisted adsorption of $\mathrm{Pb}(\mathrm{II}), \mathrm{Cd}(\mathrm{II}), \mathrm{Ni}(\mathrm{II})$ and $\mathrm{Cu}$ (II) ions from aqueous solutions by graphene oxide modified with 2,2'-dipyridylamine: Central composite design optimization. Ultrason. Sonochem. 2016, 32, 265-276. [CrossRef]

32. Li, C.; Adamcik, J.; Mezzenga, R. Biodegradable nanocomposites of amyloid fibrils and graphene with shape-memory and enzyme-sensing properties. Nat. Nanotechnol. 2012, 7, 421-427. [CrossRef] [PubMed]

33. Bello-Vieda, N.J.; Pastrana, H.F.; Garavito, M.F.; Ávila, A.G.; Celis, A.M.; Muñoz-Castro, A.; Restrepo, S.; Hurtado, J.J. Antibacterial activities of azole complexes combined with silver nanoparticles. Molecules 2018, 23, 361. [CrossRef] [PubMed]

34. Yakupova, E.I.; Bobyleva, L.G.; Vikhlyantsev, I.M.; Bobylev, A.G. Congo Red and amyloids: History and relationship. Biosci. Rep. 2019, 39. [CrossRef] [PubMed]

35. Wang, C.; Yin, J.; Wang, R.; Jiao, T.; Huang, H.; Zhou, J.; Zhang, L.; Peng, Q. Facile preparation of self-assembled polydopamine-modified electrospun fibers for highly effective removal of organic dyes. Nanomaterials 2019, 9, 116. [CrossRef]

36. Gherasim, C.V.; Bourceanu, G.; Olariu, R.I.; Arsene, C. A novel polymer inclusion membrane applied in chromium (VI) separation from aqueous solutions. J. Hazard. Mater. 2011, 197, 244-253. [CrossRef]

37. Anagnostopoulos, V.A.; Manariotis, I.D.; Karapanagioti, H.K.; Chrysikopoulos, C.V. Removal of mercury from aqueous solutions by malt spent rootlets. Chem. Eng. J. 2012, 213, 135-141. [CrossRef]

38. Veerman, C.; Ruis, H.; Sagis, L.M.C.; van der Linden, E. Effect of electrostatic interactions on the percolation concentration of fibrillar $\beta$-lactoglobulin gels. Biomacromolecules 2002, 3, 869-873. [CrossRef]

39. Bolder, S.G.; Vasbinder, A.J.; Sagis, L.M.C.; van der Linden, E. Heat-induced whey protein isolate fibrils: Conversion, hydrolysis, and disulphide bond formation. Int. Dairy J. 2007, 17, 846-853. [CrossRef]

40. Arnaudov, L.N.; de Vries, R.; Ippel, H.; van Mierlo, C.P.M. Multiple steps during the formation of beta-lactoglobulin fibrils. Biomacromolecules 2003, 4, 1614-1622. [CrossRef]

41. Aymard, P.; Nicolai, T.; Durand, D.; Clark, A. Static and Dynamic Scattering of $\beta$-Lactoglobulin Aggregates Formed after Heat-Induced Denaturation at pH 2. Macromolecules 1999, 32, 2542-2552. [CrossRef]

42. Cao, Y.; Mezzenga, R. Food protein amyloid fibrils: Origin, structure, formation, characterization, applications and health implications. Adv. Colloid Interface Sci. 2019, 269, 334-356. [CrossRef] [PubMed]

43. Zappone, B.; De Santo, M.P.; Labate, C.; Guzzi, R. Catalytic activity of copper ions in the amyloid fibrillation of b-lactoglobulin Bruno. Soft Matter 2013, 9, 2412-2419. [CrossRef]

44. Rodzik, A.; Pomastowski, P.; Sagandykova, G.N.; Buszewski, B. Interactions of whey proteins with metal ions. Int. J. Mol. Sci. 2020, 21, 2156. [CrossRef] [PubMed]

45. Yuan, Z.; Cheng, X.; Zhong, L.; Wu, R.; Zheng, Y. Preparation, characterization and performance of an electrospun carbon nanofiber mat applied in hexavalent chromium removal from aqueous solution. J. Environ. Sci. (China) 2018, 77, 75-84. [CrossRef]

46. Peydayesh, M.; Suter, M.K.; Bolisetty, S.; Boulos, S.; Handschin, S.; Nyström, L.; Mezzenga, R. Amyloid Fibrils Aerogel for Sustainable Removal of Organic Contaminants from Water. Adv. Mater. 2020, 32, 1907932. [CrossRef]

47. Bhatt, R.; Padmaj, P. A chitosan-thiomer polymer for highly efficacious adsorption of mercury. Carbohydr. Polym. 2019, 207, 663-674. [CrossRef]

48. Goers, J.; Permyakov, S.E.; Permyakov, E.A.; Uversky, V.N.; Fink, A.L. Conformational prerequisites for $\alpha$-lactalbumin fibrillation. Biochemistry 2002, 41, 12546-12551. [CrossRef]

49. Kontopidis, G.; Holt, C.; Sawyer, L. Invited Review: $\beta$-Lactoglobulin: Binding Properties, Structure, and Function. J. Dairy Sci. 2010, 87, 785-796. [CrossRef]

50. Bhowmik, M.; Debnath, A.; Saha, B. Fabrication of mixed phase CaFe2O4 and MnFe2O4 magnetic nanocomposite for enhanced and rapid adsorption of methyl orange dye: Statistical modeling by neural network and response surface methodology. J. Dispers. Sci. Technol. 2019, 41, 1-12. [CrossRef]

51. Bolder, S.G.; Sagis, L.M.C.; Venema, P.; Van Der Linden, E. Effect of stirring and seeding on whey protein fibril formation. J. Agric. Food Chem. 2007, 55, 5661-5669. [CrossRef] 
52. Adamcik, J.; Jung, J.-M.; Flakowski, J.; De Los Rios, P.; Dietler, G.; Mezzenga, R. Understanding amyloid aggregation by statistical analysis of atomic force microscopy images. Nat. Nanotechnol. 2010, 5, 423-428. [CrossRef]

53. Wang, S.S.S.; Liu, K.N.; Wen, W.S.; Wang, P. Fibril Formation of Bovine $\alpha$-Lactalbumin Is Inhibited by Glutathione. Food Biophys. 2011, 6, 138-151. [CrossRef]

54. Yang, F.; Zhang, M.; Zhou, B.R.; Chen, J.; Liang, Y. Oleic Acid Inhibits Amyloid Formation of the Intermediate of $\alpha$-Lactalbumin at Moderately Acidic pH. J. Mol. Biol. 2006, 362, 821-834. [CrossRef] [PubMed]

55. Loveday, S.M.; Wang, X.L.; Rao, M.A.; Anema, S.G.; Singh, H. Effect of pH, NaCl, $\mathrm{CaCl}_{2}$ and temperature on self-assembly of $\beta$-lactoglobulin into nanofibrils: A central composite design study. J. Agric. Food Chem. 2011, 59, 8467-8474. [CrossRef] [PubMed]

56. Zhang, Q.; Zhang, S.; Zhao, Z.; Liu, M.; Yin, X.; Zhou, Y.; Wu, Y.; Peng, Q. Highly effective lead (II) removal by sustainable alkaline activated $\beta$-lactoglobulin nanofibrils from whey protein. J. Clean. Prod. 2020, 255, 120297. [CrossRef]

57. Ji, W.; Xiao, L.; Ling, Y.; Ching, C.; Matsumoto, M.; Bisbey, R.P.; Helbling, D.E.; Dichtel, W.R. Removal of GenX and Perfluorinated Alkyl Substances from Water by Amine-Functionalized Covalent Organic Frameworks. J. Am. Chem. Soc. 2018, 140, 12677-12681. [CrossRef] [PubMed]

58. Lu, Q.; Ma, Y.; Li, H.; Guan, X.; Yusran, Y.; Xue, M.; Fang, Q.; Yan, Y.; Qiu, S.; Valtchev, V. Postsynthetic Functionalization of Three-Dimensional Covalent Organic Frameworks for Selective Extraction of Lanthanide Ions. Angew. Chem. 2018, 130, 6150-6156. [CrossRef]

59. Sun, Q.; Aguila, B.; Perman, J.; Earl, L.D.; Abney, C.W.; Cheng, Y.; Wei, H.; Nguyen, N.; Wojtas, L.; Ma, S. Postsynthetically Modified Covalent Organic Frameworks for Efficient and Effective Mercury Removal. J. Am. Chem. Soc. 2017, 139, 2786-2793. [CrossRef]

60. Ghanbarian, M.; Nabizadeh, R.; Nasseri, S.; Shemirani, F.; Mahvi, A.H.; Beyki, M.H.; Mesdaghinia, A. Potential of amino-riched nano-structured MnFe2O4@cellulose for biosorption of toxic Cr (VI): Modeling, kinetic, equilibrium and comparing studies. Int. J. Biol. Macromol. 2017, 104, 465-480. [CrossRef]

61. Tshikovhi, A.; Mishra, S.B.; Mishra, A.K. Nanocellulose-based composites for the removal of contaminants from wastewater. Int. J. Biol. Macromol. 2020, 152, 616-632. [CrossRef]

62. Huang, L.; Shen, R.; Liu, R.; Shuai, Q. Thiol-functionalized magnetic covalent organic frameworks by a cutting strategy for efficient removal of $\mathrm{Hg}^{2+}$ from water. J. Hazard. Mater. 2020, 392, 122320. [CrossRef] [PubMed]

63. Krebs, M.R.H.; Devlin, G.L.; Donald, A.M. Amyloid fibril-like structure underlies the aggregate structure across the $\mathrm{pH}$ range for $\beta$-lactoglobulin. Biophys. J. 2009, 96, 5013-5019. [CrossRef] [PubMed]

64. Jung, J.-M.; Savin, G.; Pouzot, M.; Schmitt, C.; Mezzenga, R. Structure of Heat-Induced B-Lactoglobulin Aggregates and their Complexes with Sodium-Dodecyl Sulfate. Biomacromolecules 2008, 9, 2477-2486. [CrossRef] [PubMed]

65. Nicolai, T.; Britten, M.; Schmitt, C. B-Lactoglobulin and WPI aggregates: Formation, structure and applications. Food Hydrocoll. 2011, 25, 1945-1962. [CrossRef]

66. Farrokhi, F.; Badii, F.; Ehsani, M.R.; Hashemi, M. Functional and thermal properties of nanofibrillated whey protein isolate as functions of denaturation temperature and solution $\mathrm{pH}$. Colloids Surfaces A Physicochem. Eng. Asp. 2019, 583, 124002. [CrossRef]

67. Ikeda, S.; Morris, V.J. Fine-stranded and particulate aggregates of heat-denatured whey proteins visualized by atomic force microscopy. Biomacromolecules 2002, 3, 382-389. [CrossRef]

68. Guan, C.; He, X.F.; Xu, H.H.; Shao, M.L.; Ma, J.Y.; Gao, Z.W. Comparative experiments of electrical conductivity from whey protein concentrates conventional film and nanofibril film. J. Dairy Res. 2020, 87, 103-109. [CrossRef]

69. Maity, S.; Pal, S.; Sardar, S.; Sepay, N.; Parvej, H.; Begum, S.; Dalui, R.; Das, N.; Pradhan, A.; Halder, U.C. Inhibition of amyloid fibril formation of $\beta$-lactoglobulin by natural and synthetic curcuminoids. New J. Chem. 2018, 42, 19260-19271. [CrossRef]

70. Pal, S.; Maity, S.; Sardar, S.; Chakraborty, J.; Halder, U.C. Insight into the co-solvent induced conformational changes and aggregation of bovine $\beta$-lactoglobulin. Int. J. Biol. Macromol. 2016, 84, 121-134. [CrossRef]

71. O’Loughlin, I.B.; Kelly, P.M.; Murray, B.A.; Fitzgerald, R.J.; Brodkorb, A. Concentrated whey protein ingredients: A Fourier transformed infrared spectroscopy investigation of thermally induced denaturation. Int. J. Dairy Technol. 2015, 68, 349-356. [CrossRef] 
72. Gbassi, G.; Yolou, F.; Sarr, S.; Atheba, P.; Amin, C.; Ake, M. Whey proteins analysis in aqueous medium and in artificial gastric and intestinal fluids. Int. J. Biol. Chem. Sci. 2012, 6, 1828-1837. [CrossRef]

73. Merodio-Morales, E.E.; Reynel-Ávila, H.E.; Mendoza-Castillo, D.I.; Duran-Valle, C.J.; Bonilla-Petriciolet, A. Lanthanum- and cerium-based functionalization of chars and activated carbons for the adsorption of fluoride and arsenic ions. Int. J. Environ. Sci. Technol. 2020, 17, 115-128. [CrossRef]

74. El-Hendawy, A.N.A. Variation in the FTIR spectra of a biomass under impregnation, carbonization and oxidation conditions. J. Anal. Appl. Pyrolysis 2006, 75, 159-166. [CrossRef]

75. Elizalde-González, M.P.; Mattusch, J.; Peláez-Cid, A.A.; Wennrich, R. Characterization of adsorbent materials prepared from avocado kernel seeds: Natural, activated and carbonized forms. J. Anal. Appl. Pyrolysis 2007, 78, 185-193. [CrossRef]

76. Torres, J.A.; Nogueira, F.G.E.; Silva, M.C.; Lopes, J.H.; Tavares, T.S.; Ramalho, T.C.; Corrêa, A.D. Novel eco-friendly biocatalyst: Soybean peroxidase immobilized onto activated carbon obtained from agricultural waste. RSC Adv. 2017, 7, 16460-16466. [CrossRef]

77. Andrade, S.; Veloso, C.; Fontan, R.C.; Bonomo, R.C.; Santos, L.; Brito, M.J.; Diniz, G. Chemical-activated carbon from coconut (cocos nucifera) endocarp waste and its application in the adsorption of $\beta$-lactoglobulin protein. Rev. Mex. Ing. Química 2018, 17, 463-475. [CrossRef]

78. Tabor, R.F.; Grieser, F.; Dagastine, R.; Chan, D.Y. The hydrophobic force: Measurements and methods. Phys. Chem. Chem. Phys. 2014, 16, 18065-18075. [CrossRef]

79. Wang, J.; Wang, P.; Wang, H.; Dong, J.; Chen, W.; Wang, X.; Wang, S.; Hayat, T.; Alsaedi, A.; Wang, X. Preparation of Molybdenum Disulfide Coated Mg/Al Layered Double Hydroxide Composites for Efficient Removal of Chromium(VI). ACS Sustain. Chem. Eng. 2017, 5, 7165-7174. [CrossRef]

80. Qian, L.; Wang, H.; Yang, J.; Chen, X.; Chang, X.; Nan, Y.; He, Z.; Hu, P.; Wu, W.; Liu, T. Amino Acid Cross-Linked Graphene Oxide Membranes for Metal Ions Permeation, Insertion and Antibacterial Properties. Membranes 2020, 10, 296. [CrossRef]

81. Razmi, H.; Musevi, S.J.; Mohammad-Rezaei, R. Solid phase extraction of mercury(II) using soluble eggshell membrane protein doped with reduced graphene oxide, and its quantitation by anodic stripping voltammetry. Microchim. Acta 2016, 183, 555-562. [CrossRef]

82. Kolbasov, A.; Sinha-Ray, S.; Yarin, A.L.; Pourdeyhimi, B. Heavy metal adsorption on solution-blown biopolymer nanofiber membranes. J. Memb. Sci. 2017, 530, 250-263. [CrossRef]

83. Ling, S.; Qin, Z.; Huang, W.; Cao, S.; Kaplan, D.L.; Buehler, M.J. Design and function of biomimetic multilayer water purification membranes. Sci. Adv. 2017, 3, e1601939. [CrossRef] [PubMed]

84. Manirethan, V.; Balakrishnan, R.M. Batch and continuous studies on the removal of heavy metals using biosynthesised melanin impregnated activated carbon. Environ. Technol. Innov. 2020, 20, 24723-24737. [CrossRef]

85. Goscianska, J.; Fathy, N.A.; Aboelenin, R.M.M. Adsorption of solophenyl red 3BL polyazo dye onto amine-functionalized mesoporous carbons. J. Colloid Interface Sci. 2017, 505, 593-604. [CrossRef]

86. Duan, X.L.; Yuan, C.G.; Jing, T.T.; Yuan, X.D. Removal of elemental mercury using large surface area micro-porous corn cob activated carbon by zinc chloride activation. Fuel 2019, 239, 830-840. [CrossRef]

Publisher's Note: MDPI stays neutral with regard to jurisdictional claims in published maps and institutional affiliations.

(C) 2020 by the authors. Licensee MDPI, Basel, Switzerland. This article is an open access article distributed under the terms and conditions of the Creative Commons Attribution (CC BY) license (http://creativecommons.org/licenses/by/4.0/). 